\title{
PHOTOACCLIMATORY AND PHOTOPROTECTIVE RESPONSES TO COLD VERSUS HEAT STRESS IN HIGH LATITUDE REEF CORALS ${ }^{1}$
}

\author{
Stefanie Pontasch, Paul L. Fisher \\ School of Biological Sciences, Victoria University of Wellington, Wellington 6140, New Zealand
}

Thomas Krueger

School of Biological Sciences, Victoria University of Wellington, Wellington 6140, New Zealand

Laboratory for Biological Geochemistry, School of Architecture, Civil and Environmental Engineering (ENAC), Ècole

Polytechnique Fédérale de Lausanne (EPFL), 1015 Lausanne, Switzerland

Sophie Dove

School of Biological Sciences \& ARC Centre of Excellence for Coral Reef Studies, University of Queensland, Brisbane,

QLD, 4072, Australia

Ove Hoegh-Guldberg

Global Change Institute, University of University of Queensland, Brisbane, QLD 4072, Australia

\section{William Leggat}

The College of Public Health, Medical and Veterinary Sciences \& ARC Centre of Excellence for Coral Reef Studies, James Cook

University, Townsville, QLD, 4810, Australia

and Simon K. Davy ${ }^{2}$

School of Biological Sciences, Victoria University of Wellington, Wellington 6140, New Zealand

Corals at the world's southernmost coral reef of Lord Howe Island (LHI) experience large temperature and light fluctuations and need to deal with periods of cold temperature $\left(<18^{\circ} \mathrm{C}\right)$, but few studies have investigated how corals are able to cope with these conditions. Our study characterized the response of key photophysiological parameters, as well as photoacclimatory and photoprotective pigments (chlorophylls, xanthophylls, and $\beta$ carotene), to short-term (5-d) cold stress $\left(\sim 15^{\circ} \mathbf{C}\right.$; $7^{\circ} \mathrm{C}$ below control) in three LHI coral species hosting distinct Symbiodinium ITS2 types, and compared the coral-symbiont response to that under elevated temperature $\left(\sim 29^{\circ} \mathrm{C} ; 7^{\circ} \mathrm{C}\right.$ above control). Under cold stress, Stylophora sp. hosting Symbiodinium C118 showed the strongest effects with regard to losses of photochemical performance and symbionts. Pocillopora damicornis hosting Symbiodinium C100/C118 showed less severe bleaching responses to reduced temperature than to elevated temperature, while Porites heronensis hosting Symbiodinium C111* withstood both reduced and elevated temperature. Under cold stress, photoprotection in the form of xanthophyll deepoxidation increased in unbleached $P$. heronensis

\footnotetext{
${ }^{1}$ Received 6 July 2015. Accepted 13 September 2016.

${ }^{2}$ Author for correspondence: e-mail simon.davy@vuw.ac.nz.

Editorial Responsibility: S. Lin (Associate Editor)
}

(by 178\%) and bleached Stylophora sp. (by 225\%), while under heat stress this parameter increased in unbleached $P$. heronensis (by $182 \%$ ) and in bleached $P$. damicornis (by $286 \%$ ). The xanthophyll pool size was stable in all species at all temperatures. Our comparative study demonstrates high variability in the bleaching vulnerability of these coral species to low and high thermal extremes and shows that this variability is not solely determined by the ability to activate xanthophyll de-epoxidation.

Key index words: Acropora yongei; coral bleaching; Lord Howe Island; photosynthesis; Pocillopora damicornis; Porites heronensis; Stylophora; Symbiodinium; xanthophyll de-epoxidation

Abbreviations: ${ }^{1} \mathrm{O}_{2}$, singlet oxygen; chl $a$, chlorophyll $a$; chl $c_{2}$, chlorophyll $c_{2}$; COI, mitochondrial cytochrome $c$ oxidase subunit I; Dd, diadinoxanthin; DDE, diadinoxanthin de-epoxidase; DEP, diatoxanthin epoxidase; DGGE, denaturing gradient gel electrophoresis; Dt/[Dt+Dd], xanthophyll de-epoxidation; Dt, diatoxanthin; FSW, filtered seawater; $\mathbf{F}_{v} /$ $F_{m}$, maximum quantum yield of PSII; HPLC, highpressure liquid chromatography; ITS2, internal transcribed spacer region 2; LHI, Lord Howe Island; NPQ, nonphotochemical quenching; $\mathrm{O}_{2}{ }^{-}$, superoxide anion; ORF, hypervariable mitochondrial open reading frame; PCR, polymerase chain reaction; $\mathrm{Pd}$, Pocillopora damicornis; Ph, Porites heronensis; PSII, 
photosystem II; PSP, pool (concentration) of photosynthetic pigments; $Q_{A}$, primary electron acceptor; $\mathbf{Q}_{\mathrm{B}}$, secondary electron acceptor; $Q_{\mathrm{m}}$, excitation pressure over PSII; rmANOVA, Repeated-measures analysis of variance; ROS, Reactive oxygen species; RUBISCO, ribulose-1,5-bisphosphate carboxylase oxygenase; S.E., standard error; SD, Symbiodinium cell density; $S$, Stylophora sp.; $\mathrm{T}_{\mathrm{a}}$, initial annealing temperature in polymerase chain reaction; ZEP, zeaxanthin epoxidase; $\beta$-car, $\beta$-carotene; $\Delta F / F_{m}{ }^{\prime}$, effective quantum yield of PSII

Reef-building corals associate with symbiotic dinoflagellates of the genus Symbiodinium. This symbiotic relationship is sensitive to environmental stress, exhibiting coral bleaching when stressors cause substantial degradation or loss of dinoflagellate symbionts and/or their pigments (Falkowski and Dubinsky 1981, Hoegh-Guldberg 1999). Thermal stress associated with elevated temperature anomalies is the principal cause for episodes of mass coral bleaching throughout the global distribution of reefs (Hoegh-Guldberg 1999, Lesser 2011). However, coral bleaching has also been documented under subnormal temperatures at a range of locations (Hoegh-Guldberg 1999), including the Arabian Gulf (Coles and Fadlallah 1991), southern Great Barrier Reef (Hoegh-Guldberg and Fine 2004, Hoegh-Guldberg et al. 2005), Gulf of California (LaJeunesse et al. 2010), and Florida Keys (Kemp et al. 2011). While the physiological and cellular impacts of increased temperature have been thoroughly studied (reviewed in Weis 2008), only a few studies have addressed the effects of decreased temperature on coral-Symbiodinium associations (Saxby et al. 2003, Hoegh-Guldberg and Fine 2004, HoeghGuldberg et al. 2005, Thornhill et al. 2008, LaJeunesse et al. 2010, Kemp et al. 2011, Roth et al. 2012). Saxby et al. (2003) and Kemp et al. (2011) found that the physiological response to cold stress is similar to that to heat stress and includes the loss of symbiont cells, photosynthetic pigments (PSP), and photosynthetic capacity. Roth et al. (2012) suggested that this response to chilling might only be similar to heating in the early stages. The underlying cellular and biochemical mechanisms of coldwater vulnerability remain elusive, though they might include lower RUBISCO enzyme activity (Saxby et al. 2003) or impaired thylakoid membrane fluidity (discussed in Thornhill et al. 2008, Kemp et al. 2011) under reduced temperatures. Similarly, while the photoprotective responses of corals and their symbionts to heat stress have been well studied (reviewed in Smith et al. 2005, Baird et al. 2009), photoacclimation and photoprotection during cold stress have received little attention, and there have been few comparative studies of heat and cold stress (Roth et al. 2012).
At Lord Howe Island (LHI, 31 313' S, $159^{\circ} 05^{\prime} \mathrm{E}$ ), the world's southernmost coral reef, the long-term averages of sea surface temperature for each month are between $19^{\circ} \mathrm{C}$ and $24^{\circ} \mathrm{C}$ (monthly climatology: www.coralreefwatch.noaa.gov), with a minimum point measurement of $14.5^{\circ} \mathrm{C}$ and a maximum of $28^{\circ} \mathrm{C}$ recorded in the past 10 years (www.data.a ims.gov.au). LHI coral communities are highly diverse, with at least 83 temperate, subtropical, and tropical species (Veron and Done 1979, Harriott et al. 1995) hosting at least 15 distinct Symbiodinium types, 12 of which have been proposed as being endemic, including C100, C111, and C118 (Wicks et al. 2010a). It has been shown that the combination of corals and their dinoflagellate and microbial symbionts (i.e., the holobiont) influence bleaching propensity (Sampayo et al. 2008, Fitt et al. 2009, Fisher et al. 2012) and postbleaching mortality of the host (Sampayo et al. 2008, Fitt et al. 2009). For example, Symbiodinium type determined bleaching susceptibility of the reef-building coral Pocillopora damicornis during a cold-water period in the Gulf of California; corals hosting Symbiodinium type C1b-c bleached, while those hosting Symbiodinium type D1 remained mostly unaffected (LaJeunesse et al. 2010).

The symbiotic breakdown caused by thermal stress involves a number of cellular changes within the holobiont whose sequential order is still being elucidated. Early responses within the host include apoptotic cell death in the gastrodermis (Ainsworth et al. 2008, Paxton et al. 2013) and a reduction of the coral epithelium which may precede cellular changes in the symbiont (Ainsworth et al. 2008). Furthermore, integrity, ultrastructure, and gene expression in the host's mitochondria change independently from Symbiodinium cell integrity (Dunn et al. 2012). The suppressed expression of the mitochondrial gene cytochrome $c$ may result in reduced scavenging of reactive oxygen species (ROS), so increasing the overall levels of ROS within the holobiont (Dunn et al. 2012). Within the chloroplast of symbionts, it has been proposed that thermal stress directly affects photosystem II (PSII; Warner et al. 1999), the thylakoid membranes (Iglesias-Prieto et al. 1992, Tchernov et al. 2004, Díaz-Almeyda et al. 2011), and the Calvin Cycle (Jones et al. 1998, Leggat et al. 2002, 2004), promoting electron accumulation in the chloroplast and associated overproduction of ROS (reviewed in Venn et al. 2008, Weis 2008). Further, it has been suggested that excess ROS damage host and symbiont DNA, proteins, and lipids, so accelerating the rate of damage to the photosystem and resulting in the breakdown of the symbiosis (reviewed in Venn et al. 2008, Weis 2008). However, recent studies also show that the initial production of ROS may not increase photodamage per se, but rather inhibit the repair of photodamaged components of PSII, such as the major PSII core protein D1 (Takahashi et al. 2004, 2009) and 
light-harvesting proteins (Takahashi et al. 2008). If so, small amounts of ROS could promote photoprotective steps: i.e., the down-regulation of linear electron transport could prevent the uncontrolled generation of excess ROS in the chloroplast (reviewed in Takahashi and Badger 2011).

ROS-mediated inhibition of protein synthesis is attenuated by an array of ROS-scavenging compounds, such as $\beta$-carotene quenching singlet oxygen within the chloroplast $\left({ }^{1} \mathrm{O}_{2}\right.$; Asada 2006), and by mechanisms alleviating the excess production of ROS, such as thermal dissipation of excitation energy. Other mechanisms alleviating excess ROS production include carbon fixation and alternative electron pathways such as cyclic electron flow and photorespiration in the light and chlororespiration in the dark (reviewed in Takahashi and Badger 2011, Murata et al. 2012).

Thermal dissipation is a nonphotochemical quenching (NPQ) process that allows the elimination of excessively absorbed energy at the light-harvesting complexes of PSII as heat, thus avoiding overexcitation of the photosystem (reviewed in Niyogi 1999). In dinoflagellates such as Symbiodinium spp., thermal dissipation relies on the conversion of the structural epoxy-xanthophyll diadinoxanthin (Dd) to the photoprotective epoxy-free diatoxanthin ( $\mathrm{Dt}$, xanthophyll de-epoxidation), catalyzed by diadinoxanthin de-epoxidase (DDE), which is equivalent to the conversion of violaxanthin to zeaxanthin catalyzed by violaxanthin de-epoxidase in vascular plants. In both systems, epoxidation is primarily activated by exposure to high light and subsequent acidification of the thylakoid lumen caused by light-driven photosynthetic transport. However, in contrast to vascular plants, in Dd-containing organisms DDE can be activated by a weak acidification of the thylakoid lumen that may be generated by chlororespiration in the dark or low light (reviewed in Goss and Jakob 2010). The ability of Symbiodinium to maintain Dd de-epoxidation in the dark has been demonstrated by Middlebrook et al. (2010), who showed that $75 \%$ of the xanthophyll pool was in the de-epoxidated state even after 70 min of dark acclimation, in the reef-building coral Acropora formosa. Reversal from the photoprotective to the light-harvesting state is catalyzed by the enzyme Dt epoxidase (DEP) in dinoflagellates and by zeaxanthin epoxidase (ZEP) in vascular plants. In contrast to ZEP, DEP is inhibited by a proton gradient, which is necessary to ensure Dt accumulation in conditions of high light, because DDE and DEP have highly similar rate constants (reviewed in Goss and Jakob 2010).

While several studies have addressed xanthophyll de-epoxidation and/or the role of $\beta$-carotene in Symbiodinium cells (e.g., Brown et al. 1999, Ulstrup et al. 2008, Hennige et al. 2009), and its protective role in conditions of high light (Ambarsari et al. 1997, Krämer et al. 2012) and high temperature (e.g., Dove et al. 2006, Abrego et al. 2008, Middlebrook et al. 2008), only one study has investigated xanthophyll de-epoxidation during cold-water stress $\left(21^{\circ} \mathrm{C}\right.$; Roth et al. 2012). Comparable detailed studies from corals at high latitude reefs are missing. In particular, it is not known whether corals that live close to their lower thermal thresholds (Kleypas et al. 1999) use photoacclimatory and/or photoprotective strategies to deal with cold exposure $\left(<18^{\circ} \mathrm{C}\right)$, whether in the short or long term. We therefore investigated the photophysiological response of three typical LHI holobionts (Porites heronensis C111*, Stylophora sp. C118 and P. damicornis C100/C118) to short-term cold stress. In particular, this study explored the dynamics of photoacclimatory and photoprotective pigments (chlorophylls, xanthophylls, and $\beta$-carotene) in the corals' dinoflagellate symbionts, and the possibility that the activation of thermal dissipation in the form of xanthophyll de-epoxidation might be a key strategy for withstanding bleaching at low temperature; the response was compared with that at elevated temperature.

\section{METHODS}

Sampling. In October 2010, fragments of three coral species (Table 1) were collected from the lagoon site of Sylphs Hole, LHI, Australia (3131' 249" S, 159 $03^{\prime}$ 261" E). Corals were identified as $P$. damicornis $(n=3)$, Stylophora sp. $(n=2)$ and $P$. heronensis $(n=4)$. Sample size $(n)$ refers to the number of colonies. In addition, fragments of $P$. damicornis $(n=5)$ were sampled from the lagoon reef site of Stephens Hole ( $\left.31^{\circ} 31^{\prime} 937^{\prime \prime} \mathrm{S}, 159^{\circ} 03^{\prime} 251^{\prime \prime} \mathrm{E}\right)$. We sampled $P$. damicornis from Sylphs Hole and Stephen's Hole to increase the chance of sampling different symbiont types, as this coral species has been shown to host Symbiodinium internal transcribed spacer 2 (ITS2) types C100, C103, and C118 at LHI (Wicks et al. 2010a,b). All coral species were identified based on morphological characteristics described in Veron and Stafford-Smith (2000). Because Stylophora sp. shared morphological characteristics common to both pocilloporid species, they were additionally identified using the molecular markers COI (mitochondrial cytochrome $c$ oxidase subunit I), as outlined in Folmer et al. (1994), and ORF (hypervariable mitochondrial open reading frame) as described in Flot et al. (2008). All samples were taken from a depth of 0.5-3 m during low tide. Fragments were obtained from the top of the colony to ensure that they had received a similar light regime. Sea temperatures at Sylphs Hole at the time of collection and experimentation (Austral spring) within the lagoon peaked at $22^{\circ} \mathrm{C}$ at a depth of $2.5-5.5 \mathrm{~m}$ (AIMS data center; www.data.aims.gov.au). Irradiance in the lagoon, at a depth of $0.5-3 \mathrm{~m}$, peaked at $\sim 1,750 \mu \mathrm{mol}$ photons $\cdot \mathrm{m}^{-2} \cdot \mathrm{s}^{-1}$ as measured with a submersible $\mathrm{HOBO}$ pendant data logger (ENVCO, Auckland, New Zealand) at noon. The HOBO pendant data logger was calibrated with a Li-Cor LI-189 photometer (Li-Cor, Lincoln, Nebraska, USA).

Experimental procedure. Coral explants of 1-2 cm length were immediately prepared from fragments following collection (25 explants per colony). One explant was prepared immediately for Symbiodinium genotyping (see below). Eight explants per colony were placed in one of three aerated 50 $\mathrm{L}$ tanks that were supplied with unfiltered seawater from the LHI lagoon at regular intervals (approximately every $90 \mathrm{~min}$ during daylight hours) and acclimatized to these conditions for $4 \mathrm{~d}$. During both acclimation and subsequent 
TABLE 1. Coral species and corresponding Symbiodinium ITS2 types identified by PCR-DGGE and subsequent sequencing.

\begin{tabular}{llccc}
\hline \hline Species & Family & $\begin{array}{c}\text { Symbiodinium } \\
\text { ITS2 type }\end{array}$ & $\begin{array}{c}\text { Closest GenBank } \\
\text { match (identity, \%) }\end{array}$ & GenBank \\
accession no.
\end{tabular}

temperature treatment, light intensity was reduced using shade cloth, and temperature and natural light within tanks were monitored using a submersible $\mathrm{HOBO}$ pendant logger. During acclimation, $\mathrm{F}_{\mathrm{v}} / \mathrm{F}_{\mathrm{m}}$ was monitored daily (data not shown) and stabilization of this parameter suggested that corals had acclimated adequately. Within each of the $50 \mathrm{~L}$ treatment tanks, there were eight explants from each of four $P$. heronensis colonies $(n=4)$, each of two Stylophora sp. colonies $(n=2)$ and each of eight $P$. damicomis colonies $(n=8)$.

After acclimation, coral explants were exposed to temperatures averaging: (i) $22 \pm 0.1^{\circ} \mathrm{C}$ (mean \pm S.E.; control), (ii) $15 \pm 0.1^{\circ} \mathrm{C}\left(-7^{\circ} \mathrm{C}\right.$ below control) and (iii) $29 \pm 0.1^{\circ} \mathrm{C}\left(+7^{\circ} \mathrm{C}\right.$ above control). Treatment temperatures were based on previous bleaching experiments conducted by Wicks et al. (2010b) at the same location. Furthermore, temperatures exceeding $27^{\circ} \mathrm{C}$ elicited coral bleaching at LHI (Harrison et al. 2011). The chilling/heating to respective treatment temperatures was started at $06: 00 \mathrm{~h}$ in the morning of Day 1. Treatment temperatures were attained on Day 1 at $09: 10 \mathrm{~h}\left(29^{\circ} \mathrm{C}\right)$ and 17:00 $\mathrm{h}\left(15^{\circ} \mathrm{C}\right)$. The experiment was terminated at 18:00 $\mathrm{h}$ on Day 5. Between 13:00 h and 14:00 h on Days 0 (i.e., the day prior to the start of thermal ramping), 2 , and 5 , one coral explant per coral colony was flash frozen in liquid nitrogen. Frozen samples were stored at $-80^{\circ} \mathrm{C}$ until pigment analysis.

Symbiodinium genotyping. One explant of each coral colony was airbrushed, and Symbiodinium cells isolated through repeated washes in $0.22 \mu \mathrm{m}$ filtered seawater (FSW) and preserved in sodium chloride saturated $20 \%$ dimethyl sulfoxide buffer for subsequent genotyping. Genomic DNA was isolated following the procedure of Stat et al. (2009), and isolated DNA was stored in Tris-ethylenediaminetetraacetic acid (10 mM, pH 8.0). The ITS2 of the ribosomal DNA was amplified by polymerase chain reaction (PCR) using the primers itsD (Pochon et al. 2001) and Its2CLAMP, using a touchdown protocol modified after LaJeunesse (2002). The initial annealing temperature $\left(\mathrm{T}_{\mathrm{a}}\right)$ started at $65^{\circ} \mathrm{C}$. $\mathrm{T}_{\mathrm{a}}$ was then decreased every two cycles by $1^{\circ} \mathrm{C}$ and held at the final $\mathrm{T}_{\mathrm{a}}$ of $55^{\circ} \mathrm{C}$ for an additional 15 cycles. Amplicons were separated using denaturing gradient gel electrophoresis (DGGE, BioRad DCode system) as performed in Pontasch et al. (2014), and then DNA from distinct and prominent bands was eluted overnight in $20 \mu \mathrm{L}$ sterile water, re-amplified, and sequenced in forward and reverse directions at Macrogen, South Korea. The consensus sequence was analyzed by BLAST on GenBank and compared to sequences available on Geosymbio (Franklin et al. 2012).

Chlorophyll fluorescence. Chlorophyll fluorescence of PSII was measured using a diving pulse amplitude modulated fluorometer (Walz, Effeltrich, Germany). Maximum quantum yield of PSII $\left(\mathrm{F}_{v} / \mathrm{F}_{m}\right)$ was recorded each day 30 min before sunrise $(06: 00 \mathrm{~h})$ and $30 \mathrm{~min}$ after sunset $(18: 00 \mathrm{~h})$. Effective quantum yield of PSII $\left(\Delta \mathrm{F} / \mathrm{F}_{\mathrm{m}}{ }^{\prime}\right)$ was measured between 12:00 $\mathrm{h}$ and 12:45 $\mathrm{h}$ noon. Excitation pressure over PSII $\left(Q_{\mathrm{m}}\right)$ (Iglesias-Prieto et al. 2004) was calculated as in Fisher et al. (2012):

$$
Q_{\mathrm{m}}=1-\left[\left(\Delta \mathrm{F} / \mathrm{F}_{\mathrm{m}}^{\prime}\right) \text { at noon } /\left(\mathrm{F}_{\mathrm{v}} / \mathrm{F}_{\mathrm{m}}\right) \text { at dawn of Day0 }\right]
$$

Sample preparation and analysis. Coral fragments were airbrushed in $0.22 \mu \mathrm{m} \mathrm{FSW} \mathrm{at} 4^{\circ} \mathrm{C}$. Two subsamples of the tissue slurry were removed and frozen at $-80^{\circ} \mathrm{C}$ for later determination of Symbiodinium cell density. The remaining tissue slurry was processed immediately for pigment identification and quantification. To determine Symbiodinium cell density, cells were counted in 10 replicate counts using a haemocytometer and standardized to cells $\cdot \mathrm{cm}^{-2}$ coral surface area, as determined using the paraffin wax method (Stimson and Kinzie 1991).

All steps of pigment extraction were performed at $4^{\circ} \mathrm{C}$ and pigment extracts were kept in the dark. The coral/algal homogenate was centrifuged at $4,000 \mathrm{~g}$ for $15 \mathrm{~min}$. Supernatant was discarded, $3 \mathrm{~mL}$ of high-pressure liquid chromatography (HPLC)-grade methanol was added, and the sample was vortexed and extracted for $10 \mathrm{~min}$. The extract was then centrifuged at $4,000 \mathrm{~g}$ for $3 \mathrm{~min}$. The extract was carefully removed in order to not disturb the algal pellet and the extraction repeated with new methanol. Extractions were repeated five times to ensure that all pigments were successfully extracted, and the extracts were combined and filtered through a $0.22 \mu \mathrm{m}$ cellulose acetate filter prior to pigment analysis. A subsample of the extract was analyzed by HPLC using an Agilent Technologies 1200 Series HPLC system (Agilent Technologies, Santa Clara, California, United States), in three replicate measurements (Zapata et al. 2000, Dove et al. 2006). Pigments were quantified by comparison to known concentrations of chlorophyll $a$ (chl $a)$, chlorophyll $c_{2}$ (chl $c_{2}$ ), peridinin, diadinoxanthin (Dd), diatoxanthin $(\mathrm{Dt})$, and $\beta$-carotene $(\beta$-car). These standards were obtained from DHI, Denmark. Pigment concentrations were normalized to cell number and chlorophyll $a$.

Statistical analysis. SPSS software was used for statistical analysis. Repeated-measures analysis of variance (rmANOVA) and post hoc pairwise comparison with Bonferroni adjustment were performed to determine significant changes in photophysiological parameters, symbiont density, and pigment parameters. If assumptions of normality (KolmogorovSmirnov test) and assumptions of homogeneity of variance (Levene's test) were violated, data were arcsine $\left(\mathrm{F}_{\mathrm{v}} / \mathrm{F}_{\mathrm{m}}, Q_{\mathrm{m}}\right)$ or $\log$ (pigments) transformed. When assumptions of equality of the variances between repeated measures were not met (Mauchly's test of sphericity), the Greenhouse-Geisser correction is reported. All parameters were analyzed for differences among treatments or between species on Day 0, using univariate ANOVA with post hoc Tukey's HSD comparison. Only statistically significant results are reported in the text.

\section{RESULTS}

Genetic identification of Symbiodinium. Pocillopora heronensis hosted a symbiont type that showed $99 \%$ sequence identity to type C111 (Wicks et al. 2010a) and differed by two base-pair mismatches and one base-pair deletion within the ITS2 region, and one 
base-pair mismatch in the 5.8S rRNA coding region that flanks the ITS2 region. This type is hereafter referred to as C111* (Table 1). Pocillopora damicornis hosted a mixture of Symbiodinium types C100 and C118 (Wicks et al. 2010a). Stylophora sp. hosted Symbiodinium type C118.

Maximum quantum yield of PSII. On Day $0, \mathrm{~F}_{\mathrm{v}} / \mathrm{F}_{\mathrm{m}}$ measured at 18:00 h was 0.682 \pm 0.01 (mean \pm S.E.) in $P$. heronensis, $0.667 \pm 0.01$ in $P$. damicornis, and $0.670 \pm 0.01$ in Stylophora sp.

Over a period of $5 \mathrm{~d}$, coral species responded differently to a given temperature (significant Time $\times$ Temperature $\times$ Species interaction, Table 2). While $\mathrm{F}_{\mathrm{v}} / \mathrm{F}_{\mathrm{m}}$ was relatively stable at the control temperature, this parameter declined over time in most coral associations at low and high temperature, though to differing degrees between species, and with very different responses to low and high temperature within species (Fig. 1; Table 3). In the cold treatment $\left(15^{\circ} \mathrm{C}\right), \mathrm{F}_{\mathrm{v}} / \mathrm{F}_{\mathrm{m}}$ ultimately declined by $19.7 \%$ in $P$. heronensis, $35.6 \%$ in P. damicornis and $79.8 \%$ in Stylophora sp. (Day 5 vs. Day 0). In comparison, at high temperature $\left(29^{\circ} \mathrm{C}\right), \mathrm{F}_{\mathrm{v}} / \mathrm{F}_{\mathrm{m}}$ declined by $29.2 \%$ in $P$. heronensis, $86.2 \%$ in P. damicornis, and $22 \%$ in Stylophora sp. over the $5 \mathrm{~d}$ experiment (Day 5 vs. Day 0).

Population density of symbionts. On Day 0, symbiont densities (mean \pm S.E.) were $2.68 \times 10^{6} \pm 0.19$ $\times 10^{6}$ cells $\cdot \mathrm{cm}^{-2}$ in $P$. heronensis, $1.87 \times 10^{6} \pm 0.01$ $\times 10^{6}$ cells $\cdot \mathrm{cm}^{-2}$ in $P$. damicornis, and $2.08 \times 10^{6} \pm$ $0.02 \times 10^{6}$ cells $\cdot \mathrm{cm}^{-2}$ in Stylophora sp. Univariate ANOVA $\left(F_{2,38}=11.403, P<0.001\right)$ with post hoc Tukey's HSD comparison $(P<0.001)$ revealed that symbiont density was significantly higher in $P$. heronensis than in $P$. damicornis.

While at the control temperature symbiont density was stable over time in all corals, in the cold treatment it significantly decreased in $P$. damicornis and Stylophora sp. but not in P. heronensis (Fig. 2, AC). Pocillopora damicornis lost $59 \%$ of its symbionts by the end of the experiment, while Stylophora sp. eventually lost $68 \%$ of its symbionts over this same period (Day 5 vs. Day 0). In these two coral species, the decline resulted in significantly lower symbiont densities at the end of the experiment at $15^{\circ} \mathrm{C}$ than at $22^{\circ} \mathrm{C}$ or $29^{\circ} \mathrm{C}$ (Bonferroni: $P<0.05$ for both comparisons between treatments in both species). In comparison, at elevated temperature, symbiont density was stable in two of the three species over the duration of the experiment-P. heronensis and Stylophora sp.-but in $P$. damicornis it declined even more sharply than it did in the cold (92\% decline Day 5 vs. Day 0; Fig. 2B). In this latter species, symbiont density was significantly lower after $5 \mathrm{~d}$ exposure to $29^{\circ} \mathrm{C}$ than after exposure to $15^{\circ} \mathrm{C}$ or $22^{\circ} \mathrm{C}$ (Bonferroni: $P<0.001$ for both $29^{\circ} \mathrm{C}$ vs. $15^{\circ} \mathrm{C}$ and $29^{\circ} \mathrm{C}$ vs. $\left.22^{\circ} \mathrm{C}\right)$.

Photosynthetic pigments. On Day 0, the concentration (mean \pm S.E.) of PSP (pool of chl $a$, chl $c_{2}$, peridinin) was $18.0 \pm 1.10 \mathrm{pg} \cdot \mathrm{cell}^{-1}$ in Symbiodinium $\mathrm{C} 111^{*}$ hosted by $P$. heronensis, $9.2 \pm 0.34 \mathrm{pg} \cdot \mathrm{cell}^{-1}$ in $\mathrm{C} 100 / \mathrm{C} 118$ hosted by $P$. damicornis, and $7.5 \pm 0.27 \mathrm{pg} \cdot \mathrm{cell}^{-1}$ in C118 hosted by Stylophora sp. (Fig. 2, D-F). Univariate ANOVA $\left(F_{2,39}=56.042, P<0.001\right)$ with post hoc Tukey's HSD comparison $(P<0.001)$ revealed that the concentration of pigments in Symbiodinium C111* in $P$. heronensis was significantly higher than for the other Symbiodinium types/associations.

At control and cold temperatures, the PSP pool size and concentrations of specific PSPs (chl $a$, chl $c_{2}$, and peridinin) were stable with time in all Symbiodinium types (Bonferroni: $P>0.05$ for all comparisons of days over time; Fig. 2, D-F; Table 4). Similarly, at elevated temperature, the overall PSP

TABLE 2. Results of rmANOVA analysis for the parameters: photochemical maximum quantum yield of PSII $\left(\mathrm{F}_{\mathrm{v}} / \mathrm{F}_{\mathrm{m}}\right)$; Symbiodinium density (SD); concentration of photosynthetic pigments (PSP) per cell; xanthophyll de-epoxidation (Dt/Dt+Dd); concentration of diatoxanthin (Dt) and diadinoxanthin (Dd) per chlorophyll $a$ (chl $a$ ); concentration of diatoxanthin (Dt) per chlorophyll $a(\operatorname{chl} a)$; and excitation pressure over PSII $\left(Q_{\mathrm{m}}\right)$.

\begin{tabular}{|c|c|c|c|c|c|c|c|}
\hline Variables & $\mathrm{F}_{v} / \mathrm{F}_{m}^{*}$ & $\mathrm{SD} \cdot \mathrm{cm}^{-2 *}$ & $\mathrm{PSP} \cdot \operatorname{cell}^{-1} *$ & $\mathrm{Dt} /(\mathrm{Dd}+\mathrm{Dt})$ & $(\mathrm{Dd}+\mathrm{Dt}) / \operatorname{chl} a^{*}$ & $\mathrm{Dt} / \operatorname{chl} a$ & $Q_{\mathrm{m}}^{*}$ \\
\hline \multirow[t]{2}{*}{ Time } & $<0.001$ & $<0.001$ & 0.057 & $<0.001$ & 0.015 & $<0.001$ & $<0.001$ \\
\hline & $F_{3.2}=95.1$ & $F_{1.3}=20.1$ & $F_{1.2}=3.6$ & $F_{2,31}=50.0$ & $F_{1.2}=6.0$ & $F_{2,31}=18.7$ & $F_{3.2}=80.8$ \\
\hline \multirow[t]{2}{*}{ Time $\times$ Temperature } & $<0.001$ & 0.011 & 0.160 & 0.001 & 0.314 & 0.021 & $<0.001$ \\
\hline & $F_{6.5}=15.9$ & $F_{2.5}=4.5$ & $F_{2.5}=2.3$ & $F_{4,62}=5.6$ & $F_{2.4}=1.2$ & $F_{4,62}=3.1$ & $F_{6.4}=6.2$ \\
\hline \multirow[t]{2}{*}{ Time $\times$ Species } & $<0.001$ & 0.006 & 0.070 & 0.009 & 0.338 & 0.008 & $<0.001$ \\
\hline & $F_{6.5}=7.4$ & $F_{2.5}=5.2$ & $F_{2.5}=2.7$ & $F_{4,62}=3.8$ & $F_{2.4}=1.1$ & $F_{4,62}=3.8$ & $F_{6.4}=9.8$ \\
\hline \multirow[t]{2}{*}{ Time $\times$ Temperature $\times$ Species } & $<0.001$ & $<0.001$ & 0.133 & $<0.001$ & 0.279 & 0.003 & $<0.001$ \\
\hline & $F_{13}=9.5$ & $F_{5.1}=7$ & $F_{4.9}=1.8$ & $F_{8,62}=6.9$ & $F_{4.8}=1.3$ & $F_{8,62}=3.3$ & $F_{12.8}=5.2$ \\
\hline Error (Time) & 106.9 & 39.3 & 39.6 & 31 & 38.1 & 31 & 105.7 \\
\hline \multirow[t]{2}{*}{ Temperature } & $<0.001$ & 0.003 & 0.053 & 0.002 & 0.683 & 0.035 & $<0.001$ \\
\hline & $F_{2}=20.7$ & $F_{2}=7.0$ & $F_{2}=3.2$ & $F_{2}=7.8$ & $F_{2}=0.4$ & $F_{2}=3.7$ & $F_{2}=47.9$ \\
\hline \multirow[t]{2}{*}{ Species } & 0.06 & $<0.001$ & $<0.001$ & $<0.001$ & 0.366 & 0.003 & $<0.001$ \\
\hline & $F_{2}=3.1$ & $F_{2}=19.7$ & $F_{2}=46.2$ & $F_{2}=10.1$ & $F_{2}=1.0$ & $F_{2}=6.8$ & $F_{2}=42.9$ \\
\hline \multirow[t]{2}{*}{ Temperature $\times$ Species } & $<0.001$ & 0.002 & 0.185 & 0.326 & 0.846 & 0.655 & $<0.001$ \\
\hline & $F_{4}=12.5$ & $F_{4}=5.6$ & $F_{4}=1.7$ & $F_{4}=1.2$ & $F_{4}=0.3$ & $F_{4}=0.6$ & $F_{4}=12.4$ \\
\hline Error & 33 & 32 & 32 & 32 & 32 & 32 & 33 \\
\hline
\end{tabular}

*Greenhouse-Geisser correction is reported.

Bold numbers highlight significant differences $(p \leq 0.05)$. 
FIG. 1. Effect of temperature over a $5 \mathrm{~d}$ period on maximum quantum yield of PSII $\left(\mathrm{F}_{\mathrm{v}} / \mathrm{F}_{\mathrm{m}}\right)$ in (A) Porites heronensis hosting Symbiodinium $\mathrm{C} 111^{*}, n=4$, (B) Pocillopora damicomis hosting C100/ C118, $n=8$, and (C) Stylophora sp. hosting C118, $n=2$. Values are means \pm S.E. Significant differences are reported for (a) $22^{\circ} \mathrm{C}$ versus $29^{\circ} \mathrm{C}$, (b) $22^{\circ} \mathrm{C}$ versus $15^{\circ} \mathrm{C}$, and (c) $15^{\circ} \mathrm{C}$ versus $29^{\circ} \mathrm{C}$ at the level of $P<0.05$ (rmANOVA and pairwise comparison with Bonferroni correction)

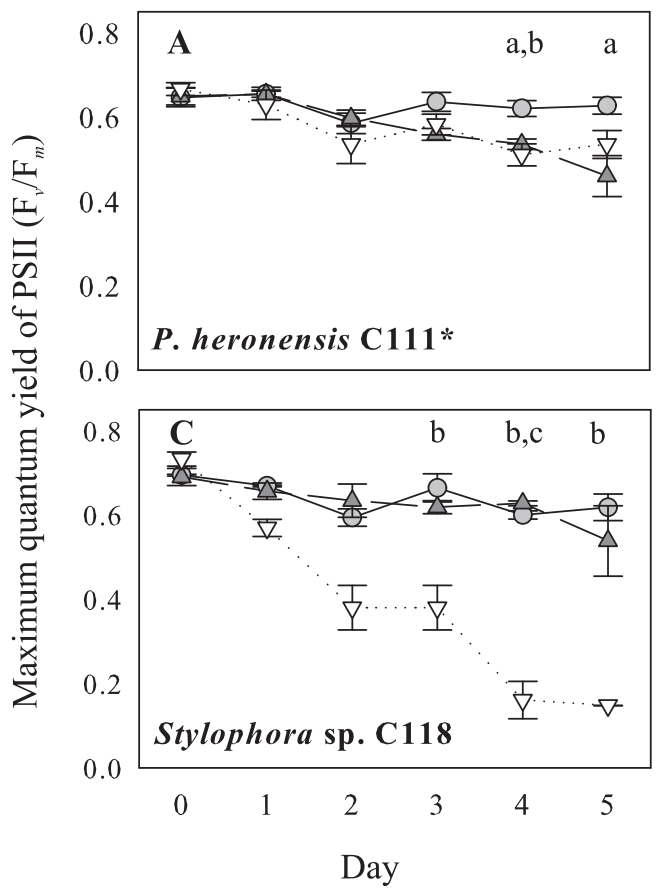

TABLE 3. Results of rmANOVA analysis (effect of Time $x$ Temperature) when each coral-symbiont association is analyzed separately. The parameters are maximum quantum yield of PSII $\left(\mathrm{F}_{\mathrm{v}} / \mathrm{F}_{\mathrm{m}}\right)$; Symbiodinium density (SD); pool of photosynthetic pigments (PSP); xanthophyll de-epoxidation (Dt/ $(\mathrm{Dt}+\mathrm{Dd}))$; pool of diadinoxanthin (Dd) and diatoxanthin (Dt) per chlorophyll $a(\operatorname{chl} a)$; Dt per chl $a$; and excitation pressure over PSII $\left(Q_{\mathrm{m}}\right)$.

\begin{tabular}{|c|c|c|c|}
\hline Parameter & $\begin{array}{l}\text { Porites heronensis } \\
\text { C111* }\end{array}$ & $\begin{array}{l}\text { Pocillopora damicomis } \\
\text { C100/C118 }\end{array}$ & $\begin{array}{l}\text { Stylophora } \\
\text { sp. C118 }\end{array}$ \\
\hline $\begin{array}{l}\mathrm{F}_{\mathrm{v}} / \mathrm{F}_{\mathrm{m}} \\
\quad F_{(d f, \text { Error } d f)} \\
\quad P\end{array}$ & $\begin{array}{l}5.1_{(4.3,19.5)^{\dagger}} \\
0.005\end{array}$ & $\begin{array}{l}30.2_{(5.5,57.6)^{\dagger}} \\
<0.001\end{array}$ & $\begin{array}{l}12.5_{(5,7.4)^{\dagger}} \\
0.002^{-}\end{array}$ \\
\hline SD & & & \\
\hline $\begin{array}{l}F_{(d f, \text { Error } d f)} \\
P\end{array}$ & $\begin{array}{l}\mathrm{ns} \\
\mathrm{ns}\end{array}$ & $\begin{array}{l}5.3_{(4,38)} \\
0.002\end{array}$ & $\begin{array}{l}8(4,4) \\
0.035\end{array}$ \\
\hline PSP & & & \\
\hline $\begin{array}{l}F_{(d f, \text { Error } d f)} \\
P\end{array}$ & $\begin{array}{l}\text { ns } \\
\text { ns }\end{array}$ & $\begin{array}{l}5.3_{(4,38)} \\
0.002\end{array}$ & $\begin{array}{l}\text { ns } \\
\text { ns }\end{array}$ \\
\hline $\begin{array}{c}\mathrm{Dt} /(\mathrm{Dt}+\mathrm{Dd}) \\
F_{(d f, \text { Error } d f)} \\
P\end{array}$ & $\begin{array}{l}8.5_{(4,16)} \\
0.001\end{array}$ & $\begin{aligned} & 13.3_{(4,38)} \\
< & 0.001\end{aligned}$ & $\begin{array}{l}\mathrm{ns} \\
\mathrm{ns}\end{array}$ \\
\hline $\begin{array}{c}(\mathrm{Dt}+\mathrm{Dd}) / \mathrm{chl} \\
\left.F_{(d f, \text { Error }} d f\right) \\
P\end{array}$ & $\begin{array}{l}\text { ns } \\
\text { ns }\end{array}$ & $\begin{array}{l}\mathrm{ns} \\
\mathrm{ns}\end{array}$ & $\begin{array}{l}\mathrm{ns} \\
\mathrm{ns}\end{array}$ \\
\hline $\begin{array}{l}\mathrm{Dt} / \operatorname{chl} a \\
\quad F_{(d f, \text { Error } d f)} \\
P\end{array}$ & $\begin{array}{l}7.3_{(4,16)} \\
0.001\end{array}$ & $\begin{array}{l}6.2(4,38) \\
0.001\end{array}$ & $\begin{array}{l}7(4,4) \\
0.043\end{array}$ \\
\hline $\begin{array}{l}Q_{\mathrm{m}} \\
\quad F_{(d f, \text { Error } d f)} \\
P\end{array}$ & $\begin{array}{l}6.3_{(10,10)} \\
0.004\end{array}$ & $\begin{array}{l}21_{(5.7 .59 .4)^{\dagger}}<0.001\end{array}$ & $\begin{array}{l}\mathrm{ns} \\
\mathrm{ns}\end{array}$ \\
\hline
\end{tabular}

${ }^{\dagger}$ Greenhouse-Geisser correction reported.

Only significant effects $(p \leq 0.05)$ are shown.

$\mathrm{df}=$ degrees of freedom; ns $=$ not significant on the level $P>0.05$.

pool size remained relatively constant in $P$. heronensis and Stylophora sp. (Fig. 2, D and F, Table 3), though in C111* in $P$. heronensis the chl a pool size had declined by $25.3 \%$ at the end of the experiment (Bonferroni: $P<0.001$; Table 4), so that on Day 5, the concentration of chl $a$ was significantly lower at $29^{\circ} \mathrm{C}$ than at both $15^{\circ} \mathrm{C}$ and $22^{\circ} \mathrm{C}$ (Bonferroni: $P<0.05$ for both comparisons). Moreover, the PSP pool size at elevated temperature declined in C100/C118 in P. damicornis (Fig. 2E), so that by Day 5 it was significantly lower than at both $22^{\circ} \mathrm{C}$ and $15^{\circ} \mathrm{C}$ (Bonferroni: $P<0.01$ for $29^{\circ} \mathrm{C}$ vs. $22^{\circ} \mathrm{C}$ and $P<0.05$ for $29^{\circ} \mathrm{C}$ vs. $15^{\circ} \mathrm{C}$, respectively). This decline was associated with a $74.4 \%$ loss of chl $a$, $73.3 \%$ loss of chl $c_{2}$, and $53 \%$ loss of peridinin, as outlined in Table 4 (Day 5 vs. Day 0 ).

Xanthophyll de-epoxidation and $\beta$-carotene. On Day 0, xanthophyll de-epoxidation $(\mathrm{Dt} /[\mathrm{Dt}+\mathrm{Dd}])$ was $0.25 \pm 0.015$ (mean \pm S.E.) in Symbiodinium C111* hosted by $P$. heronensis, $0.22 \pm 0.013$ in C100/C118 hosted by $P$. damicornis, and $0.25 \pm 0.025$ in $\mathrm{C} 118$ hosted by Stylophora sp. (Fig. 3, A-C).

Over the $5 \mathrm{~d}$ period at the control temperature, xanthophyll de-epoxidation remained stable in P. damicornis (Bonferroni: $P>0.05$ ) but not in Stylophora sp. and $P$. heronensis, where it increased and decreased, respectively (Bonferroni: $P<0.001$, Day 5 vs. Day 0 ; and $P<0.05$, Day 5 vs. Day 2, respectively). Nevertheless, after $5 \mathrm{~d}$ in the cold, Symbiodinium C118 in Stylophora sp. increased xanthophyll de-epoxidation over time at least 2-fold (Fig. 3C). Symbiodinium C111* in $P$. heronensis significantly increased xanthophyll de-epoxidation 1.8-fold over time, to $0.43 \pm 0.013$, resulting in a significantly higher rate than at the control temperature at the same time $(0.24 \pm 0.023$; Fig. 3A; Table 3$)$. In comparison, at high temperature, both $\mathrm{C} 111^{*}$ in $P$. heronensis and C100/C118 in P. damicornis enhanced 


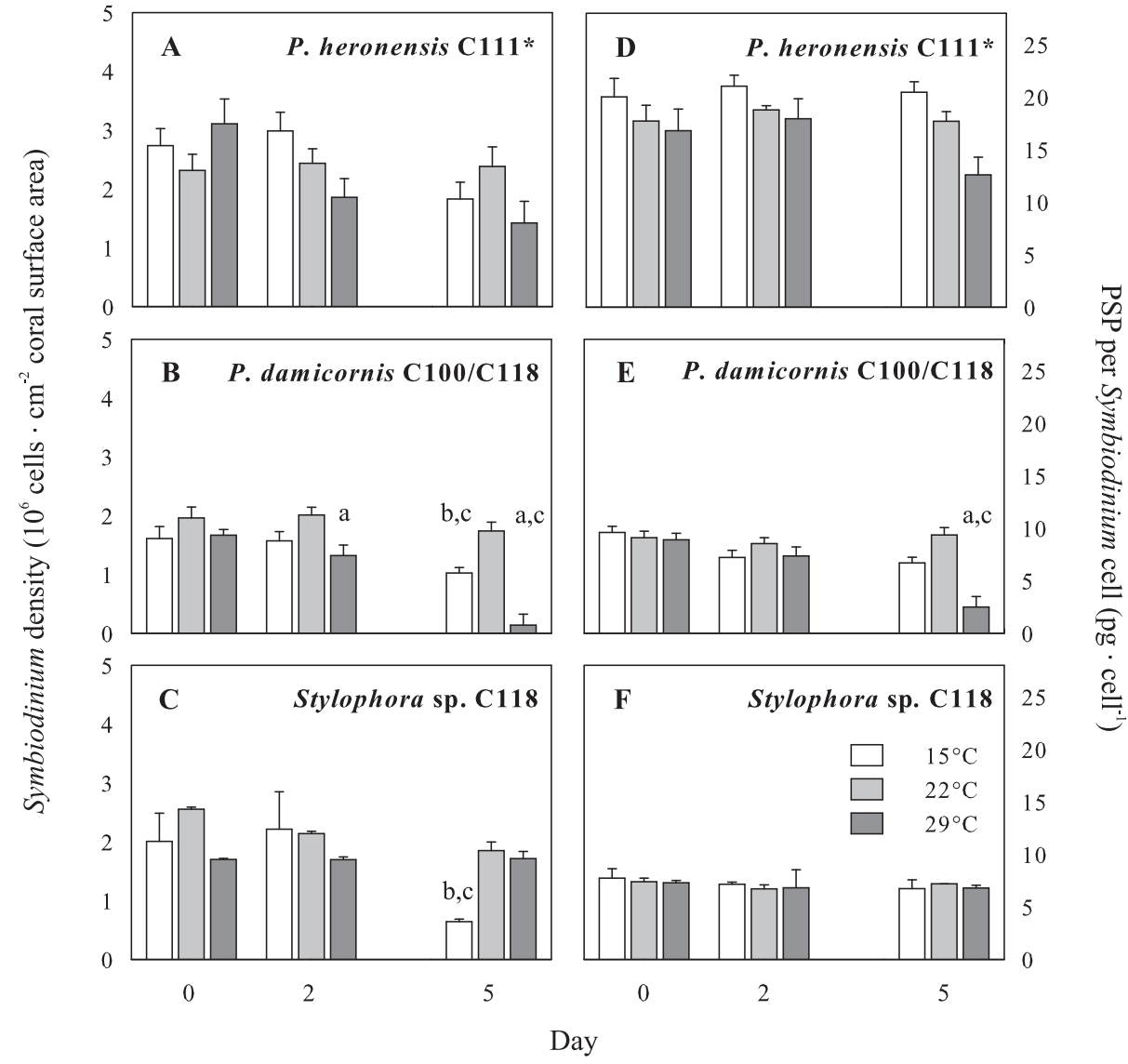

FIG. 2. Symbiodinium cell density in million cells per $\mathrm{cm}^{2}$ coral surface area $(\mathrm{A}-\mathrm{C})$ and pool of photosynthetic pigments (PSP, comprising chl $a$, chl $c_{2}$, and peridinin) (D-F) in $\mathrm{pg} \cdot \mathrm{cell}^{-1}$ for (A, D) Porites heronensis hosting Symbiodinium C111*, $n=4$; (B, E) Pocillopora damicornis hosting $\mathrm{C} 100 / \mathrm{C} 118, n=8$; and $(\mathrm{C}, \mathrm{F})$ Stylophora sp. hosting C118, $n=2$. Presented are mean values \pm S.E. Significant differences are reported for (a) $22^{\circ} \mathrm{C}$ versus $29^{\circ} \mathrm{C}$, (b) $22^{\circ} \mathrm{C}$ versus $15^{\circ} \mathrm{C}$, and (c) $15^{\circ} \mathrm{C}$ versus $29^{\circ} \mathrm{C}$ at the level of $P<0.05$ (rmANOVA and pairwise comparison with Bonferroni correction).

TABLE 4. Concentration of light-harvesting pigments chlorophyll $a$ (chl $a$ ), chlorophyll $c_{2}\left(\mathrm{chl} c_{2}\right)$, peridinin (pg cell ${ }^{-1}$ ) on Days 0, 2, and 5 of the temperature treatment for Symbiodinium C111* in Porites heronensis (Ph), C100/C118 in Pocillopora damicornis (Pd), and C118 in Stylophora sp. (S).

\begin{tabular}{|c|c|c|c|c|c|c|c|c|c|}
\hline & \multicolumn{3}{|c|}{$\operatorname{chl} a$} & \multicolumn{3}{|c|}{$\operatorname{chl} c_{2}$} & \multicolumn{3}{|c|}{ Peridinin } \\
\hline & 0 & 2 & 5 & 0 & 2 & 5 & 0 & 2 & 5 \\
\hline \multicolumn{10}{|l|}{$\mathbf{P h}$} \\
\hline \multicolumn{10}{|l|}{ C111* } \\
\hline $15^{\circ} \mathrm{C}$ & $11.0 \pm 0.9$ & $11.3 \pm 0.6$ & $11.3 \pm 0.4$ & $2.7 \pm 0.2$ & $2.8 \pm 0.1$ & $2.6 \pm 0.3$ & $6.4 \pm 0.7$ & $6.9 \pm 0.4$ & $6.5 \pm 0.4$ \\
\hline $22^{\circ} \mathrm{C}$ & $9.8 \pm 0.9$ & $10.2 \pm 0.2$ & $9.6 \pm 0.4$ & $2.3 \pm 1.2$ & $2.5 \pm 0.1$ & $2.4 \pm 0.2$ & $5.7 \pm 0.5$ & $6.1 \pm 0.2$ & $5.7 \pm 0.4$ \\
\hline $29^{\circ} \mathrm{C}$ & $9.1 \pm 1.1$ & $9.8 \pm 1.0$ & $6.8 \pm 1.0^{\mathrm{a}, \mathrm{b}}$ & $2.3 \pm 0.3$ & $2.4 \pm 0.3$ & $1.6 \pm 0.3$ & $5.5 \pm 0.6$ & $5.8 \pm 0.6$ & $4.2 \pm 0.5$ \\
\hline \multicolumn{10}{|l|}{ Pd } \\
\hline \multicolumn{10}{|c|}{ C100/C118 } \\
\hline $15^{\circ} \mathrm{C}$ & $5.2 \pm 0.4$ & $3.9 \pm 0.4$ & $3.5 \pm 0.3$ & $1.5 \pm 0.1$ & $1.2 \pm 0.1$ & $1.2 \pm 0.1$ & $2.9 \pm 0.2$ & $2.1 \pm 0.2$ & $2.0 \pm 0.2$ \\
\hline $22^{\circ} \mathrm{C}$ & $5.0 \pm 0.4$ & $4.7 \pm 0.3$ & $5.0 \pm 0.3$ & $1.3 \pm 0.1$ & $1.5 \pm 0.1$ & $1.5 \pm 0.2$ & $2.8 \pm 0.2$ & $2.4 \pm 0.1$ & $2.8 \pm 0.2$ \\
\hline $29^{\circ} \mathrm{C}$ & $4.7 \pm 0.4$ & $3.9 \pm 0.5$ & $1.2 \pm 0.5^{\mathrm{a}, \mathrm{b}}$ & $1.5 \pm 0.1$ & $1.3 \pm 0.1$ & $0.4 \pm 0.1^{\mathrm{a}, \mathrm{b}}$ & $2.7 \pm 0.2$ & $2.2 \pm 0.3$ & $1.3 \pm 0.5^{\mathrm{a}, \mathrm{b}}$ \\
\hline $\mathbf{S}$ & & & & & & & & & \\
\hline \multicolumn{10}{|l|}{ C118 } \\
\hline $15^{\circ} \mathrm{C}$ & $4.6 \pm 0.5$ & $4.2 \pm 0.1$ & $3.9 \pm 0.5$ & $1.2 \pm 0.2$ & $1.0 \pm 0.1$ & $1.0 \pm 0.1$ & $2.0 \pm 0.3$ & $1.9 \pm 0.1$ & $1.8 \pm 0.3$ \\
\hline $22^{\circ} \mathrm{C}$ & $4.4 \pm 0.2$ & $3.8 \pm 0.3$ & $4.2 \pm 0.1$ & $1.1 \pm 0.1$ & $1.0 \pm 0.1$ & $1.1 \pm 0.1$ & $1.9 \pm 0.1$ & $1.9 \pm 0.0$ & $1.9 \pm 0.1$ \\
\hline $29^{\circ} \mathrm{C}$ & $4.4 \pm 0.1$ & $3.8 \pm 1.2$ & $4.0 \pm 0.2$ & $1.0 \pm 0.0$ & $1.2 \pm 0.1$ & $1.0 \pm 0.0$ & $1.9 \pm 0.1$ & $1.9 \pm 0.4$ & $1.8 \pm 0.1$ \\
\hline
\end{tabular}

Significant differences $(P<0.05)$ from values at $15^{\circ} \mathrm{C}\left({ }^{\mathbf{a}}\right)$ and $22^{\circ} \mathrm{C}\left({ }^{\mathbf{b}}\right)$ based on rmANOVA analysis with post hoc Bonferroni corrected pairwise comparison, are highlighted in bold.

their rates of xanthophyll de-epoxidation to $0.43 \pm 0.021$ and $0.55 \pm 0.030$, respectively (Fig. 3, $\mathrm{A}$ and $\mathrm{C})$, resulting in significantly higher rates at the end of the experiment than at both the control and cold temperatures (Bonferroni: $P<0.001$ for both comparisons, $29^{\circ} \mathrm{C}$ vs. $15^{\circ} \mathrm{C}$ and $29^{\circ} \mathrm{C}$ vs. $\left.22^{\circ} \mathrm{C}\right)$.

Light intensity ( $\mu \mathrm{mol}$ photons $\cdot \mathrm{m}^{-2} \cdot \mathrm{s}^{-1}$ ) was lowest on Day 1 and highest on Day 2 and averaged $1,095 \pm 119$ on Day $0,561 \pm 79$ on Day 1 , 


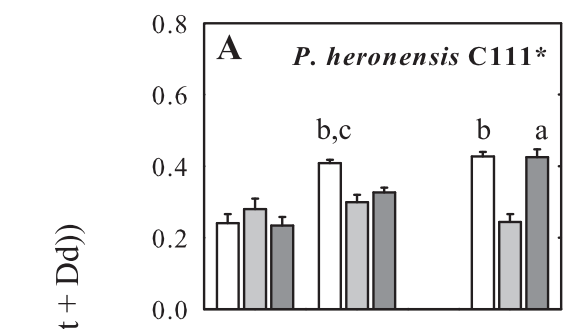

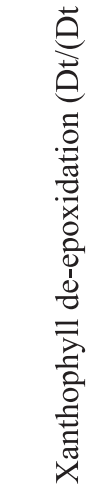

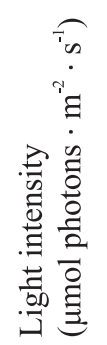

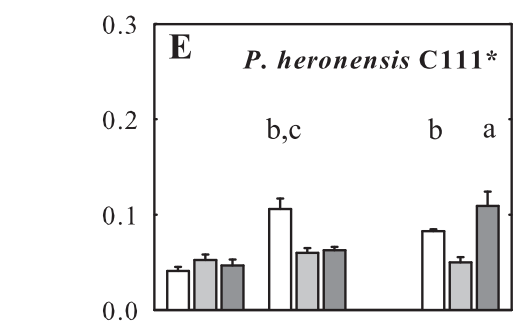
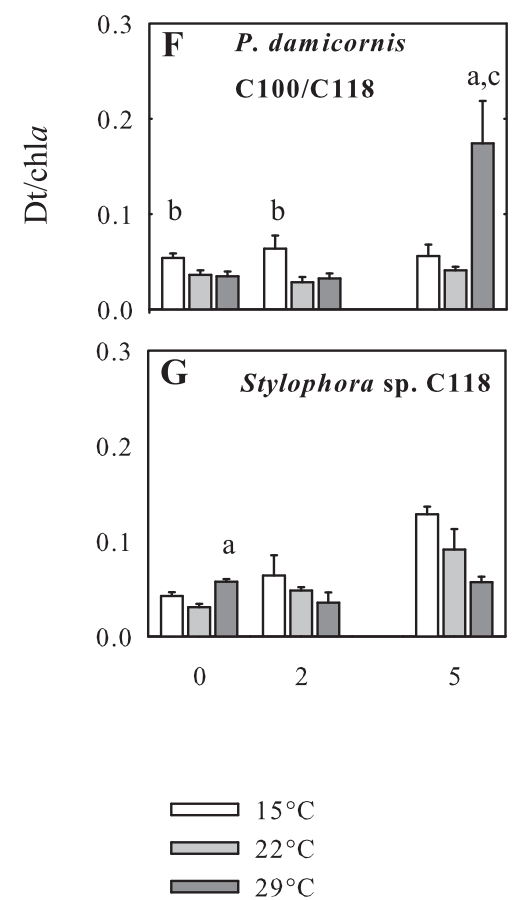

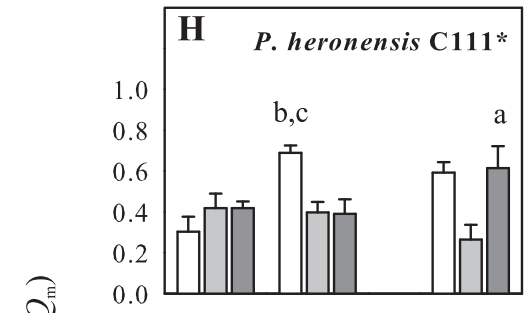

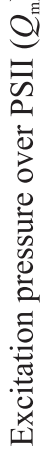
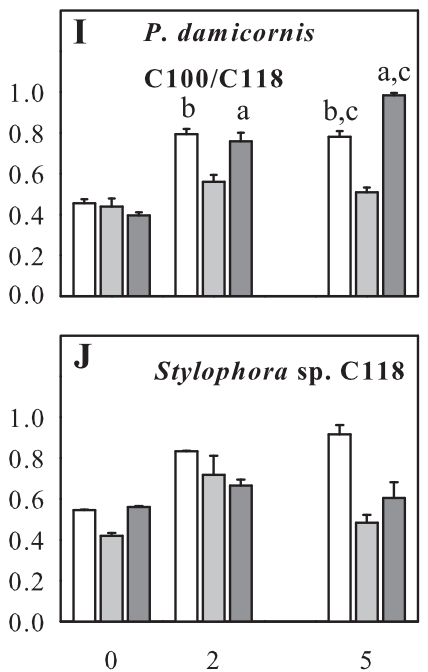

FIG. 3. Xanthophyll de-epoxidation (A-C), light intensity (D), concentration of diatoxanthin per chlorophyll $a$ (Dt/chl $a$ ) (E-G) and excitation pressure over PSII, $Q_{\mathrm{m}}(\mathrm{H}-\mathrm{J})$ over a 5 d period in (A, E, H) Porites heronensis hosting Symbiodinium C111*, $n=4$; (B, F, I) Pocillopora damicornis hosting C100/C118, $n=8$; and (C, G, J) Stylophora sp. hosting C118, $n=2$. Light intensities are means \pm S.E. between 12:00 $\mathrm{h}$ and 13:00 $\mathrm{h}$, when chlorophyll fluorescence was measured. All other values are means \pm S.E. Significant differences are reported for (a) $22^{\circ} \mathrm{C}$ versus $29^{\circ} \mathrm{C}$, (b) $22^{\circ} \mathrm{C}$ versus $15^{\circ} \mathrm{C}$, and (c) $15^{\circ} \mathrm{C}$ versus $29^{\circ} \mathrm{C}$ at the level of $P<0.05$ (rmANOVA and pairwise comparison with Bonferroni correction).

$1,694 \pm 117$ on Day 2, $1,042 \pm 162$ on Day 3, $1,064 \pm 71$ on Day 4, and $906 \pm 12$ on Day 5 , between 12:00 $\mathrm{h}$ and 13:00 h (Fig. 3D).

The concentration of diatoxanthin relative to chl $a(\mathrm{Dt} / \mathrm{chl} a)$ was similar between coral species at the beginning of the experiment (ANOVA: $P>0.05$; Fig. 3, E-G). Over the duration of the experiment, control values of $\mathrm{Dt} / \mathrm{chl} a$ were stable in $P$. heronensis and $P$. damicornis (Bonferroni: $P>0.05$ for both species), but increased in Stylophora sp. (Bonferroni: $P<0.01$, Day 5 vs. Day 0 ). In the cold treatment, Dt/chl $a$ increased over time in $P$. heronensis and Stylophora sp. (Bonferroni: $P<0.01$, Day 5 vs. Day 0 for both species), while at high temperature, this parameter increased in $P$. heronensis (Bonferroni: $P<0.01$, Day 5 vs. Day 0 ) and $P$. damicornis (Bonferroni: $P<0.001$, Day 5 vs. Day 0 ). When $\mathrm{Dt} / \mathrm{chl} a$ was compared between treatments on Day 5, it was significantly higher at both the high and low temperatures than at the control temperature in $P$. heronensis (Fig. 3E). In contrast, in $P$. damicornis, Dt/chl $a$ at high temperature was significantly greater than at both the low and control temperatures (Fig. 3F).

Xanthophyll pool size relative to chl $a((\mathrm{Dt}+$ $\mathrm{Dd}) / \mathrm{chl} a$ ) was similar between species and remained constant over time in all corals at all temperatures (ANOVA and rmANOVA: $P>0.05$ for all comparisons; Table 5).

At the beginning of the experiment, $P$. heronensis had a higher concentration of $\beta$-carotene relative to chl $a$ than $P$. damicornis, as revealed by univariate ANOVA $\left(F_{2,39}=8.498, P=0.001\right)$ with post hoc Tukey's HSD comparison $(P<0.05)$. This parameter did not vary over time in any species or thermal treatment (rmANOVA: $P>0.05$; Table 5). 
Excitation pressure over PSII. On Day 0, excitation pressure $\left(Q_{\mathrm{m}}\right)$ averaged $0.38 \pm 0.04$ (mean \pm S.E.) in $P$. heronensis, $0.42 \pm 0.01$ in $P$. damicornis, and $0.51 \pm 0.03$ in Stylophora sp. (Fig. 3, H-J) and was significantly higher in Stylophora sp. than in P. heronensis (Tukey HSD: $P<0.05$ ).

The temporal response to a given temperature was distinct between corals (significant Time $\times$ Temperature $\times$ Species interaction, Table 2). On Days 0, 2, and $5, Q_{\mathrm{m}}$ was stable in all corals at the control temperature (Bonferroni: $P>0.05$ for all comparisons of days over time in all species), but over this period at both the low and high temperatures, all corals except Stylophora sp. responded significantly (Fig. 3, $\mathrm{H}-\mathrm{J}$, Table 3). Specifically, on Day 2, $Q_{\mathrm{m}}$ was elevated at cold temperature relative to the control in $P$. heronensis (Bonferroni: $P=0.01$ ) and $P$. damicornis $(P<0.01)$, and this elevation persisted until the end of the experiment in the latter species $(P<0.001)$. Similarly, $Q_{\mathrm{m}}$ was elevated by high temperature in $P$. damicornis $(P=0.01)$ on Day 2 and in $P$. heronensis $(P<0.05)$ and $P$. damicornis $(P<0.001)$ on Day 5 . Of note, $P$. damicornis responded more strongly to the high temperature than the cold one on Day 5 (Bonferroni: $P<0.001$ ).

\section{DISCUSSION}

Lord Howe corals exhibit highly variable responses to thermal stress. When compared with tropical sites, sea temperatures and light penetration at high latitude sites, such as LHI, are seasonally lower and annually more variable (Kleypas et al. 1999). It is not known whether corals that live close to their lower thermal thresholds (Kleypas et al. 1999) use photoacclimatory and/or photoprotective strategies to deal with cold exposure, whether in the short or long term. The plasticity of light-harvesting (chlorophyll $a, \mathrm{c}_{2}$, and peridinin) and photoprotective pigments (xanthophylls and $\beta$-carotene) at cold temperatures has received little attention, and there have been few comparative studies of heat and cold stress (Wicks et al. 2010b, Roth et al. 2012). Therefore, this study addressed the plasticity of light-harvesting and photoprotective pigments in symbiotic dinoflagellates which might be a key parameter for understanding the ability of corals to deal with environmental change at high latitudes, and in particular to cope with lower temperatures. This issue is particularly important given that, with global warming, climate variability is projected to increase and more frequent cold temperature anomalies are expected to occur (Urban et al. 2000, Abram et al. 2008).

This study demonstrates that corals on the high latitude coral reef of LHI exhibit highly variable responses to short-term cold stress $\left(\sim 7^{\circ} \mathrm{C}\right.$ below the control temperature) and short-term heat stress $\left(\sim 7^{\circ} \mathrm{C}\right.$ above the control temperature, $\sim 4^{\circ} \mathrm{C}$ above the bleaching threshold predicted by Coral Watch at www.coralreefwatch.noaa.gov). Porites heronensis hosting Symbiodinium C111* did not bleach and showed similar photophysiological responses to both cold and heat stress. Pocillopora damicornis hosting Symbiodinium C100/C118 bleached less severely when exposed to cold stress than heat stress, corroborating results obtained for the same coral species at the same location (Wicks et al. 2010b). Indeed, these authors suggested that $P$. damicornis at Lord Howe might be specialized for cooler temperatures, and this study supports this hypothesis. That $P$. damicornis was the more bleaching-susceptible coral at increased temperature was consistent with previous field observations that showed that Pocilloporidae were among the more bleaching-susceptible corals during the LHI coral bleaching event of March 2010 , when seawater temperatures exceeded $27^{\circ} \mathrm{C}$ (Harrison et al. 2011). Finally, Stylophora sp. hosting Symbiodinium C118 bleached under cold stress but

TABLE 5. Concentration of photoprotective pigments $\beta$-carotene/chl $a$, and the xanthophylls diadinoxanthin (Dd) and diatoxanthin (Dt)/chl $a$ on Days 0,2 , and 5 of the temperature treatment for Symbiodinium C111* in Porites heronensis (Ph), C100/C118 in Pocillopora damicornis (Pd), and C118 in Stylophora sp. (S).

\begin{tabular}{|c|c|c|c|c|c|c|}
\hline & \multicolumn{3}{|c|}{$\beta$ - carotene $/$ chl $a$} & \multicolumn{3}{|c|}{$(\mathrm{Dd}+\mathrm{Dt}) / \mathrm{chl} a$} \\
\hline & 0 & 2 & 5 & 0 & 2 & 5 \\
\hline \multicolumn{7}{|l|}{$\mathbf{P h}$} \\
\hline \multicolumn{7}{|l|}{ C111* } \\
\hline $15^{\circ} \mathrm{C}$ & $0.057 \pm 0.002$ & $0.062 \pm 0.004$ & $0.048 \pm 0.004$ & $0.17 \pm 0.003$ & $0.21 \pm 0.002$ & $0.19 \pm 0.003$ \\
\hline $22^{\circ} \mathrm{C}$ & $0.075 \pm 0.017$ & $0.057 \pm 0.004$ & $0.060 \pm 0.001$ & $0.19 \pm 0.002$ & $0.20 \pm 0.005$ & $0.20 \pm 0.005$ \\
\hline $29^{\circ} \mathrm{C}$ & $0.060 \pm 0.002$ & $0.054 \pm 0.003$ & $0.093 \pm 0.031$ & $0.20 \pm 0.007$ & $0.19 \pm 0.005$ & $0.26 \pm 0.043$ \\
\hline \\
\hline \multicolumn{7}{|c|}{$\mathrm{C} 100 / \mathrm{C} 118$} \\
\hline $15^{\circ} \mathrm{C}$ & $0.040 \pm 0.007$ & $0.033 \pm 0.009$ & $0.026 \pm 0.006$ & $0.19 \pm 0.007$ & $0.19 \pm 0.016$ & $0.18 \pm 0.014$ \\
\hline $22^{\circ} \mathrm{C}$ & $0.045 \pm 0.003$ & $0.028 \pm 0.007$ & $0.038 \pm 0.007$ & $0.19 \pm 0.012$ & $0.15 \pm 0.010$ & $0.19 \pm 0.010$ \\
\hline $29^{\circ} \mathrm{C}$ & $0.038 \pm 0.006$ & $0.025 \pm 0.006$ & $0.031 \pm 0.013$ & $0.18 \pm 0.009$ & $0.14 \pm 0.008$ & $0.30 \pm 0.063$ \\
\hline \multicolumn{7}{|c|}{ 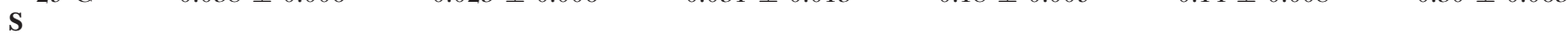 } \\
\hline \multicolumn{7}{|l|}{ C118 } \\
\hline $15^{\circ} \mathrm{C}$ & $0.043 \pm 0.000$ & $0.034 \pm 0.001$ & $0.043 \pm 0.003$ & $0.17 \pm 0.003$ & $0.16 \pm 0.020$ & $0.20 \pm 0.008$ \\
\hline $22^{\circ} \mathrm{C}$ & $0.041 \pm 0.001$ & $0.031 \pm 0.003$ & $0.046 \pm 0.004$ & $0.17 \pm 0.002$ & $0.15 \pm 0.004$ & $0.21 \pm 0.029$ \\
\hline $29^{\circ} \mathrm{C}$ & $0.041 \pm 0.013$ & $0.021 \pm 0.007$ & $0.038 \pm 0.005$ & $0.19 \pm 0.007$ & $0.15 \pm 0.005$ & $0.17 \pm 0.005$ \\
\hline
\end{tabular}


not under heat stress. In a comparable study, Roth et al. (2012) found that, in the branching coral Acropora yongei, cold stress induces acute stress in both symbionts and coral host, though heat stress is more harmful in the long-term. Unfortunately, due to experimental constraints imposed by the remoteness of our study site, we could not perform a longterm experiment here, so we cannot predict how the three species of corals and their symbionts would perform when exposed to a more prolonged period of cold $(>5 \mathrm{~d})$. However, as with heat stress, acute cold stress may reduce symbiont density (Steen and Muscatine 1987, Saxby et al. 2003, Kemp et al. 2011) and photosynthetic capacity (Kemp et al. 2011), with potential negative consequences for the host, such as reduced growth or impaired reproductive capacity. As such, projected periods of cold sea surface temperature will likely put additional pressures on the stability of coral reef communities that also have to cope with warming oceans in the long term.

In our study, bleaching resistance and performance of PSII photochemistry under cold and heat stress were not consistently correlated with symbiont properties such as enhanced use of xanthophyll deepoxidation. Under cold stress, symbionts in both bleaching-resistant $P$. heronensis and bleached Stylophora sp. increased xanthophyll de-epoxidation, while this capacity remained unchanged in symbionts of bleaching-susceptible $P$. damicornis. While enhanced xanthophyll de-epoxidation might act photoprotectively to prevent cold-water bleaching in $P$. heronensis, this mechanism was not sufficient to avoid bleaching in Stylophora sp. Similarly, under heat stress, symbionts in both bleaching-resistant $P$. heronensis and bleached $P$. damicornis increased xanthophyll de-epoxidation, while this parameter remained unchanged in symbionts of unbleached Stylophora sp. A similar lack of correlation between xanthophyll de-epoxidation and bleaching susceptibility was demonstrated previously in heat-stressed Symbiodinium cells (Venn et al. 2006). Collectively, these results demonstrate that the susceptibility of a coral to cold stress is not determined by its capacity for xanthophyll de-epoxidation, consistent with previously reported results for heat-stressed corals. This highlights the complex physiological responses involved in cold and heat stress.

Mode of bleaching. Although coral bleaching varied in intensity, a similar mode of bleaching across species and temperatures was observed: symbiont cells were expelled before a significant reduction in the total pool of PSPs per symbiont cell could be observed. These results agree with earlier findings of symbiont loss due to cold stress in the sea anemone Aiptasia pulchella (Steen and Muscatine 1987), and the corals Montipora digitata (Saxby et al. 2003), Montastraea faveolata, Siderastrea siderea (Kemp et al. 2011), and A. yongei (Roth et al. 2012), and heat stress in the corals Stylophora pistillata and Seriatopora hystrix (Hoegh-Guldberg and Smith 1989). The observed mode of bleaching contrasts with findings in cold-stressed Porites astreoides (Kemp et al. 2011), as well as heat-stressed Acropora digitifera (Takahashi et al. 2004) and Montipora monasteriata (Dove et al. 2006), that reduced their cell-specific pigment concentration but not their Symbiodinium cell density. It has been suggested before that the rate of heating/ chilling (slow vs. rapid) influences the cellular mechanisms of bleaching, i.e., in situ degradation, host cell apoptosis, and necrosis (Krueger et al. 2015). Therefore, our different findings may result from different heating and hence bleaching rates; due to technical constraints in the field, a fairly fast rate of heating/chilling was used in this study. Symbiont densities declined in response to cold stress in Stylophora sp. without concurrent pigment loss in its symbionts. In contrast, the mixed population of C100/C118 in P. damicornis suffered dramatically reduced cell numbers and concentrations of all major PSPs when exposed to short-term cold stress and, to a greater extent, when exposed to shortterm heat stress. Thermally induced concurrent loss of symbiont cells and pigments has been described before (Kleppel et al. 1989) and might exacerbate the process of bleaching that was observed in P. damicornis: the reduction of cells and pigments increases light scattering from the underlying coral skeleton and enhances the internal light intensity (Enríquez et al. 2005).

Chlorophyll fluorescence and photoprotection by xanthophyll de-epoxidation. Although it has been shown that symbionts expelled from $P$. damicornis due to thermal stress can be fully photosynthetically functional (Ralph et al. 2001), a decline in photosynthetic performance in remaining symbionts, which can be estimated by chlorophyll fluorescence of PSII, has been shown to occur during coral bleaching (Hoegh-Guldberg 1999). In this study, in both pocilloporid species, the loss of symbiont cells both under cold stress ( $P$. damicornis and Stylophora sp.) and heat stress ( $P$. damicornis) was accompanied by a pronounced decline in maximum quantum efficiency of PSII $\left(\mathrm{F}_{\mathrm{v}} / \mathrm{F}_{\mathrm{m}}\right)$; the decline in the cold was fastest and steepest in Stylophora sp. Possible underlying causes for the declines in $\mathrm{F}_{\mathrm{v}} / \mathrm{F}_{\mathrm{m}}$ under cold and heat stress are (i) enhanced Dt accumulation and thermal dissipation, which might be sustained in the dark by a trans-thylakoidal $\Delta \mathrm{pH}$ gradient, possibly generated by chlororespiration (Hill and Ralph 2005, Reynolds et al. 2008); and/or (ii) the inactivation of PSII reaction centers, likely coupled with ROS-mediated inhibition of their repair and the inability to transfer electrons past PSII (Tyystjärvi 2008, Takahashi and Badger 2011). Wicks et al. (2010b) showed that both high and low temperature had a similar site of impact on PSII and the redox state of the primary $\left(Q_{\mathrm{A}}\right)$ and secondary $\left(\mathrm{Q}_{\mathrm{B}}\right)$ electron acceptors in Symbiodinium cells in $P$. damicornis from Lord Howe. Specifically, perhaps as a result of inactivation of 
PSII centers, the rate of $Q_{A}$ reduction and the capacity to transport electrons from $Q_{\mathrm{A}}$ through $\mathrm{Q}_{\mathrm{B}}$, and consequently the photochemical capacity of PSII, declined under both cold and heat stress, though the impact was less severe in the cold. The excitation pressure over PSII $\left(Q_{\mathrm{m}}\right)$ is a parameter that is influenced by NPQ processes. $Q_{\mathrm{m}}$ is also dependent on the light intensity, which varied over the course of our experiment, with the lowest light intensities on Day 1 and highest light intensities on Day 2. Despite these variations in light intensity, $Q_{\mathrm{m}}$ dynamics over time can be compared between treatments because all corals had the same light history. In this study, all corals, with the exception of Stylophora sp, had higher $Q_{\mathrm{m}}$ values after $5 \mathrm{~d}$ at both $15^{\circ} \mathrm{C}$ and $29^{\circ} \mathrm{C}$ than at the control temperature. The increase of $Q_{\mathrm{m}}$ was due to a decrease in the effective quantum yield $\left(\Delta \mathrm{F} / \mathrm{F}_{\mathrm{m}}{ }^{\prime}\right)$ at peak solar radiation, which has been described in previous studies (e.g., Hoegh-Guldberg and Jones 1999, Gorbunov et al. 2001). This drop in $\Delta \mathrm{F} / \mathrm{F}_{\mathrm{m}}{ }^{\prime}$ at noon has been linked to PSII core rearrangement or degradation (photoinactivation; Niyogi 1999), as well as increased NPQ associated with increased xanthophyll de-epoxidation (Brown et al. 1999, Warner and Berry-Lowe 2006). In algae that contain Dd and Dt, NPQ associated with thermal dissipation seems to be directly correlated with the concentration of Dt (Goss and Jakob 2010). Porites heronensis consistently increased xanthophyll de-epoxidation and $\mathrm{Dt} / \mathrm{chl} a$ with $Q_{\mathrm{m}}$ at both low and high temperatures, suggesting that at both temperatures NPQ is efficiently activated through xanthophyll de-epoxidation, while Stylophora sp. increased xanthophyll de-epoxidation and Dt/chl $a$ at $15^{\circ} \mathrm{C}$ and $22^{\circ} \mathrm{C}$ but not at $29^{\circ} \mathrm{C}$, indicating increased thermal dissipation at lower temperatures only. This latter response is especially interesting, as it suggests a greater need for photoprotection under cold stress, and greater resilience to warmer temperatures, in Stylophora sp. than in the other species. Alternatively, Stylophora sp. might use different protective mechanisms, so negating the necessity of NPQ at high temperatures. Greater resilience to high temperature in this species is corroborated by declines in the photochemical efficiency of PSII (Fig. 1C) and symbiont density (Fig. 2C) under cold stress and maintenance of these parameters at high temperature. In our study, differences in xanthophyll de-epoxidation and $\mathrm{Dt} / \mathrm{chl} a$ among treatments on Day 0 in $P$. damicornis (higher values for both parameters at $15^{\circ} \mathrm{C}$ than at $22^{\circ} \mathrm{C}$ and $29^{\circ} \mathrm{C}$, see Fig. 3, B and F) might be due to the sampling regime (corals at $15^{\circ} \mathrm{C}$ had been sampled last and therefore were exposed at least 15 min longer to peak solar irradiation, corresponding to a light intensity ( $\mu$ mol photons $\cdot \mathrm{m}^{-2} \cdot \mathrm{s}^{-1}$ ) of $\sim 1,095$ on Day 0, 1,694 on Day 2, and 906 on Day 5). However, this sampling regime was maintained throughout the experiment, so we believe that comparisons to the control over time are meaningful. At $15^{\circ} \mathrm{C}, Q_{\mathrm{m}}$ but not xanthophyll de-epoxidation or Dt/chl $a$ was increased over time relative to the control in $P$. damicornis, while at $29^{\circ} \mathrm{C}$, xanthophyll de-epoxidation, $\mathrm{Dt} / \mathrm{chl} a$, and $Q_{\mathrm{m}}$ were enhanced. These results suggest that, at low temperatures, alternative quenching mechanisms are activated in these species. These may include reaction center inactivation due to PSIIcore rearrangement or degradation of their symbionts, as has been observed in heat-stressed corals (Takahashi et al. 2004).

The quantum efficiency of electron transport past PSII is affected by NPQ mechanisms, such as thermal dissipation, and also by the ability to transfer electrons to acceptors downstream of PSII (Ort and Baker 2002). The latter is affected by the availability of electron sinks such as $\mathrm{CO}_{2}$ and $\mathrm{O}_{2}$ (Badger et al. 2000, Ort and Baker 2002). At sub- or supra-optimal temperatures, the affinity of ribulose-1,5-bisphosphate carboxylase oxygenase (RUBISCO), the keyenzyme of the Calvin-Benson cycle, for $\mathrm{CO}_{2}$ decreases due to altered kinetic properties of the enzyme. Saxby et al. (2003) suggested that coldinduced impairment of the Calvin-Benson cycle might underlie reduced photosynthetic electron transport and subsequent overreductions of the light reactions. A similar model has been proposed for heat-stressed symbiotic dinoflagellates (Jones et al. 1998). Recently, different capabilities of carbon fixation at elevated temperature have been demonstrated for symbionts of type/clade C1 and D (Baker et al. 2013). Under thermal extremes, the electron pressure over PSII may accumulate because light energy is continuously absorbed but not processed adequately. Downstream of PSII, electrons may alternatively be processed by (i) the reduction of $\mathrm{O}_{2}$ by the Mehler reaction, which generates $\mathrm{O}_{2}{ }^{-}$ and other ROS in subsequent reduction processes as part of the water-water cycle (Asada 1999); or (ii) the reduction of $\mathrm{O}_{2}$ in the photorespiratory pathway (Ort and Baker 2002). RUBISCO catalyzes the initial oxygenation in the photorespiratory cycle and its efficiency is temperature-dependent, i.e., while low temperatures lead to a decreased affinity for both $\mathrm{CO}_{2}$ and $\mathrm{O}_{2}$ uptake, high temperatures decrease the affinity of RUBISCO for $\mathrm{CO}_{2}$ and increase the affinity for $\mathrm{O}_{2}$. Hence, at low temperatures photorespiration might be less important as an electron sink than at high temperatures, and the Mehler reaction might be more efficient in reducing $\mathrm{O}_{2}$ (Badger et al. 2000, Ort and Baker 2002). What is more, Mehler $\mathrm{O}_{2}$ uptake might be facilitated by higher $\mathrm{O}_{2}$ solubility at cold temperatures. With ongoing cold stress, increased reduction of $\mathrm{O}_{2}$ could cause an imbalance of ROS and detoxifying enzymes (Lesser 2011), and hence cellular damage and/or the inhibition of the repair of photodamaged PSII reaction centers (Takahashi and Badger 2011). This may ultimately result in reduced photochemical efficiency and increased $Q_{\mathrm{m}}$ at cold temperatures, as observed in P. damicornis in this study. 
Compared with other species, $P$. heronensis and its symbionts had a higher baseline concentration of $\beta$ carotene relative to chlorophyll $a$. This might contribute to the observed bleaching resistance at both low and high temperatures in this species, because in marine organisms $\beta$-carotene is one of the major antioxidants responsible for the quenching of singlet oxygen $\left({ }^{1} \mathrm{O}_{2}\right.$; Ben-Amotz et al. 1989). Removal of excessive ${ }^{1} \mathrm{O}_{2}$ by $\beta$-carotene might suppress ROSmediated inhibition of protein synthesis, as has been proposed for $\alpha$-tocopherol, and promote the repair of reaction centers (Murata et al. 2012). However, levels of $\beta$-carotene relative to chlorophyll $a$ did not increase over time at high or low temperature, either in $P$. heronensis or in $P$. damicornis, agreeing with findings in Goniastrea aspera when naturally bleached by high temperature (Ambarsari et al. 1997), and findings in Porites porites, Porites astreoides (both Symbiodinium clade A), Montastraea franksi, Favia fragum (both Symbiodinium clade B), and Montastraea cavernosa (Symbiodinium clade C) when experimentally exposed to elevated temperature and irradiation (Venn et al. 2006). In contrast to these results, however, Hill et al. (2012) found that the proportion of $\beta$-carotene relative to chlorophyll $a$ in A. millepora and P. damicornis was correlated to bleaching sensitivity, implicating enhanced detoxification of potentially harmful ROS. Still, it seems that an increased level of $\beta$-carotene is not a common major response to high temperature.

\section{CONCLUSION}

This study investigated the impact of cold stress versus heat stress on coral species at the southern end of their distribution, focusing on key photophysiological parameters of their symbiotic algae. While overall, the physiological impacts of cold stress were very similar to those observed under heat stress (loss of photochemical efficiency and loss of symbionts), we found host species-specific differences that did not depend on symbiont-specific properties. In particular, photoprotection in the form of xanthophyll de-epoxidation was not clearly linked to resistance to low temperature. Although the underlying cellular and biochemical mechanisms that determine resilience or susceptibility of the holobiont to low temperature appear to be as complex as those observed at high temperature, they are unlikely to be identical. To predict a coral's resilience to low temperature, key cellular adaptation mechanisms need to be identified. Such adaptation mechanisms might include the maintenance of enzyme activity, protein turnover or thylakoid membrane fluidity in their symbiotic algae under periods of cold stress, and should be the focus of future work.

We thank I. Kerr and S. Gudge (MPA, LHI), B. Busteed (Howea Divers), A. Carroll and S. Dalton (Southern Cross
University, Australia) for field and logistical support, S. Wilkinson for help with statistical analysis, P. Ralph and K. Ryan for insightful discussions on the work, and an anonymous reviewer for their insightful and constructive comments. The study was funded by a Royal Society of New Zealand Marsden Fund grant (contract number VUW0902) to SKD, SD, PLF, OH-G, and WL.

Abram, N. J., Gagan, M. K., Cole, J. E., Hantoro, W. S. \& Mudelsee, M. 2008. Recent intensification of tropical climate variability in the Indian Ocean. Nat. Geosci. 12:849-53.

Abrego, D., Ulstrup, K. E., Willis, B. L. \& Van Oppen, M. J. H. 2008. Species-specific interactions between algal endosymbionts and coral hosts define their bleaching response to heat and light stress. Proc. R. Soc. Lond. B Biol. Sci. 275:2273-82.

Ainsworth, T., Hoegh-Guldberg, O., Heron, S., Skirving, W. \& Leggat, W. 2008. Early cellular changes are indicators of prebleaching thermal stress in the coral host. J. Exp. Mar. Biol. Ecol. 364:63-71.

Ambarsari, I., Brown, B., Barlow, R., Britton, G. \& Cummings, D. 1997. Fluctuations in algal chlorophyll and carotenoid pigments during solar bleaching in the coral Goniastrea aspera at Phuket, Thailand. Mar. Ecol. Prog. Ser. 159:303-7.

Asada, K. 1999. The water-water cycle in chloroplasts: scavenging of active oxygens and dissipation of excess photons. Ann. Rev. Plant Biol. 50:601-39.

Asada, K. 2006. Production and scavenging of reactive oxygen species in chloroplasts and their functions. Plant Physiol. 141:391-6.

Badger, M. R., Von Caemmerer, S., Ruuska, S. \& Nakano, H. 2000. Electron flow to oxygen in higher plants and algae: rates and control of direct photoreduction (Mehler reaction) and RUBISCO oxygenase. Philos. Trans. R. Soc. B 355:143346.

Baird, A. H., Bhagooli, R., Ralph, P. J. \& Takahashi, S. 2009. Coral bleaching: the role of the host. Trends Ecol. Evol. 24:16-20.

Baker, D. M., Andras, J. P., Jordan-Garza, A. G. \& Fogel, M. L. 2013. Nitrate competition in a coral symbiosis varies with temperature among Symbiodinium clades. ISME J. $7: 1248-51$.

Ben-Amotz, A., Shaish, A. \& Avron, M. 1989. Mode of action of the massively accumulated $\beta$-carotene of Dunaliella bardawil in protecting the alga against damage by excess irradiation. Plant Physiol. 91:1040-3.

Brown, B., Ambarsari, I., Warner, M., Fitt, W., Dunne, R., Gibb, S. \& Cummings, D. 1999. Diurnal changes in photochemical efficiency and xanthophyll concentrations in shallow water reef corals: evidence for photoinhibition and photoprotection. Coral Reefs 18:99-105.

Coles, S. L. \& Fadlallah, Y. H. 1991. Reef coral survival and mortality at low temperatures in the Arabian Gulf: new speciesspecific lower temperature limits. Coral Reefs 9:231-7.

Díaz-Almeyda, E., Thomé, P. E., El Hafidi, M. \& Iglesias-Prieto, R. 2011. Differential stability of photosynthetic membranes and fatty acid composition at elevated temperature in Symbiodinium. Coral Reefs 30:217-25.

Dove, S., Ortiz, J. C., Enriquez, S., Fine, M., Fisher, P., IglesiasPrieto, R., Thornhill, D. \& Hoegh-Guldberg, O. 2006. Response of holosymbiont pigments from the scleractinian coral Montipora monasteriata to short-term heat stress. Limnol. Oceanogr. 51:1149-58

Dunn, S. R., Pernice, M., Green, K., Hoegh-Guldberg, O. \& Dove, S. G. 2012. Thermal stress promotes host mitochondrial degradation in symbiotic cnidarians: are the batteries of the reef going to run out? PLoS ONE 7:e39024.

Enríquez, S., Méndez, E. R. \& Iglesias-Prieto, R. 2005. Multiple scattering on coral skeletons enhances light absorption by symbiotic algae. Limnol. Oceanogr. 50:1025-32.

Falkowski, P. G. \& Dubinsky, Z. 1981. Light-shade adaptation of Stylophora pistillata, a hermatypic coral from the Gulf of Eilat. Nature 289:172-4. 
Fisher, P. L., Malme, M. \& Dove, S. 2012. The effect of temperature stress on coral-Symbiodinium associations containing distinct symbiont types. Coral Reefs 31:473-85.

Fitt, W. K., Gates, R. D., Hoegh-Guldberg, O., Bythell, J. C., Jatkar, A., Grotolli, A. G., Gomez, M., Fisher, P. L., LaJeunesse, T. C. \& Pantos, O. 2009. Response of two species of IndoPacific corals, Porites cylindrica and Stylophora pistillata, to short-term thermal stress: the host does matter in determining the tolerance of corals to bleaching. J. Exp. Mar. Biol. Ecol. 373:102-10.

Flot, J. F., Magalon, H., Cruaud, C., Couloux, A. \& Tillier, S. 2008. Patterns of genetic structure among Hawaiian corals of the genus Pocillopora yield clusters of individuals that are compatible with morphology. Coral Reef Biol. 331:239-47.

Folmer, O., Black, M., Hoeh, W., Lutz, R. \& Vrijenhoek, R. 1994. DNA primers for amplification of mitochondrial cytochrome c oxidase subunit I from diverse metazoan invertebrates. Mol. Mar. Biol. Biotech. 3:294-9.

Franklin, E. C., Stat, M., Pochon, X., Putnam, H. M. \& Gates, R. D. 2012. GeoSymbio: a hybrid, cloud-based web application of global geospatial bioinformatics and ecoinformatics for Symbiodinium-host symbioses. Mol. Ecol. Res. 12:369-73.

Gorbunov, M. Y., Kolber, Z. S., Lesser, M. P. \& Falkowski, P. G. 2001. Photosynthesis and photoprotection in symbiotic corals. Limnol. Oceanogr. 46:75-85.

Goss, R. \& Jakob, T. 2010. Regulation and function of xanthophyll cycle-dependent photoprotection in algae. Photosynth. Res. 106:103-22.

Harriott, V. J., Harrison, P. L. \& Banks, S. A. 1995. The coral communities of Lord Howe Island. Mar. Freshw. Res. 46:457-65.

Harrison, P. L., Dalton, S. J. \& Carroll, A. G. 2011. Extensive coral bleaching on the world's southernmost coral reef at Lord Howe Island, Australia. Coral Reefs 30:775.

Hennige, S. J., Suggett, D. J., Warner, M. E., McDougall, K. E. \& Smith, D. J. 2009. Photobiology of Symbiodinium revisited: bio-physical and bio-optical signatures. Coral Reefs 28:179-95.

Hill, R., Larkum, A. W. D., Prášil, O., Kramer, D. M., Szabó, M., Kumar, V. \& Ralph, P. J. 2012. Light-induced dissociation of antenna complexes in the symbionts of scleractinian corals correlates with sensitivity to coral bleaching. Coral Reefs 31:963-75.

Hill, R. \& Ralph, P. J. 2005. Diel and seasonal changes in fluorescence rise kinetics of three scleractinian corals. Funct. Plant Biol. 32:549-59.

Hoegh-Guldberg, O. 1999. Climate change, coral bleaching and the future of the world's coral reefs. Mar. Freshw. Res. 50:839-66.

Hoegh-Guldberg, O. \& Fine, M. 2004. Low temperatures cause coral bleaching. Coral Reefs 23:444.

Hoegh-Guldberg, O., Fine, M., Skirving, W., Johnstone, R., Dove, S. \& Strong, A. 2005. Coral bleaching following wintry weather. Limnol. Oceanogr. 50:265-71.

Hoegh-Guldberg, O. \& Jones, R. J. 1999. Photoinhibition and photoprotection in symbiotic dinoflagellates from reef-building corals. Mar. Ecol. Prog. Ser. 183:73-86.

Hoegh-Guldberg, O. \& Smith, G. J. 1989. The effect of sudden changes in temperature, light and salinity on the population density and export of zooxanthellae from the reef corals Stylophora pistillata Esper and Seriatopora hystrix Dana. J. Exp. Mar. Biol. Ecol. 129:279-303.

Iglesias-Prieto, R., Beltran, V. H., LaJeunesse, T. C., Reyes-Bonilla, H. \& Thome, P. E. 2004. Different algal symbionts explain the vertical distribution of dominant reef corals in the eastern Pacific. Proc. R. Soc. Lond. B Biol. Sci. 271:1757-63.

Iglesias-Prieto, R., Matta, J. L., Robins, W. A. \& Trench, R. K. 1992. Photosynthetic response to elevated temperature in the symbiotic dinoflagellate Symbiodinium microadriaticum in culture. Proc. Natl. Acad. Sci. USA 89:10302-5.

Jones, R. J., Hoegh-Guldberg, O., Larkum, A. W. D. \& Schreiber, U. 1998. Temperature-induced bleaching of corals begins with impairment of the $\mathrm{CO}_{2}$ fixation mechanism in zooxanthellae. Plant Cell Environ. 21:1219-30.
Kemp, D. W., Oakley, C. A., Thornhill, D. J., Newcomb, L. A., Schmidt, G. W. \& Fitt, W. K. 2011. Catastrophic mortality on inshore coral reefs of the Florida Keys due to severe low-temperature stress. Glob. Change Biol. 17:3468-77.

Kleppel, G., Dodge, R. \& Reese, C. 1989. Changes in pigmentation associated with the bleaching of stony corals. Limnol. Oceanogr. 34:1331-5.

Kleypas, J. A., McManus, J. W. \& Meñez, L. A. B. 1999. Environmental limits to coral reef development: where do we draw the line? Am. Zool. 39:146-59.

Krämer, W. E., Caamaño-Ricken, I., Richter, C. \& Bischof, K. 2012. Dynamic regulation of photoprotection determines thermal tolerance of two phylotypes of Symbiodinium clade A at two Photon fluence rates. Photochem. Photobiol. 88:398-413.

Krueger, T., Hawkins, T. D., Becker, S., Pontasch, S., Dove, S., Hoegh-Guldberg, O., Leggat, W., Fisher, P. L. \& Davy, S. K. 2015. Differential coral bleaching - Contrasting the activity and response of enzymatic antioxidants in symbiotic partners under thermal stress. Comp. Biochem. Physiol. A Mol. Integr. Physiol. 190:15-25.

LaJeunesse, T. C. 2002. Diversity and community structure of symbiotic dinoflagellates from Caribbean coral reefs. Mar. Biol. 141:387-400.

LaJeunesse, T. C., Smith, R., Walther, M., Pinzón, J., Pettay, D. T., McGinley, M., Aschaffenburg, M., Medina-Rosas, P., CupulMagaña, A. L. \& Pérez, A. L. 2010. Host-symbiont recombination versus natural selection in the response of coral-dinoflagellate symbioses to environmental disturbance. Proc. $R$. Soc. Lond. B Biol. Sci. 277:2925-34.

Leggat, W., Marendy, E. M., Baillie, B., Whitney, S. M., Ludwig, M., Badger, M. R. \& Yellowlees, D. 2002. Dinoflagellate symbioses: strategies and adaptations for the acquisition and fixation of inorganic carbon. Funct. Plant Biol. 29:309-22.

Leggat, W., Whitney, S. \& Yellowlees, D. 2004. Is coral bleaching due to the instability of the zooxanthellae dark reactions? Symbiosis 37:137-53.

Lesser, M. P. 2011. Coral bleaching: causes and mechanisms. In Dubinsky, Z. \& Stambler, N. [Eds.] Coral Reefs: An Ecosystem in Transition. Springer, New York, pp. 405-19.

Middlebrook, R., Anthony, K. R. N., Hoegh-Guldberg, O. \& Dove, S. 2010. Heating rate and symbiont productivity are key factors determining thermal stress in the reef-building coral Acropora formosa. J. Exp. Biol. 213:1026-34.

Middlebrook, R., Hoegh-Guldberg, O. \& Leggat, W. 2008. The effect of thermal history on the susceptibility of reef-building corals to thermal stress. J. Exp. Biol. 211:1050-6.

Murata, N., Allakhverdiev, S. I. \& Nishiyama, Y. 2012. The mechanism of photoinhibition in vivo: re-evaluation of the roles of catalase, $\alpha$-tocopherol, non-photochemical quenching, and electron transport. BBA-Bioenergetics 1817:1127-33.

Niyogi, K. K. 1999. Photoprotection revisited: genetic and molecular approaches. Ann. Rev. Plant Phys. 50:333-59.

Ort, D. R. \& Baker, N. R. 2002. A photoprotective role for $\mathrm{O}_{2}$ as an alternative electron sink in photosynthesis? Curr. Opin. Plant Biol. 5:193-8.

Paxton, S. W., Davy, S. K. \& Weis, V. M. 2013. Stress and death of cnidarian host cells play a role in cnidarian bleaching. J. Exp. Biol. 216:2813-20.

Pochon, X., Pawlowski, J., Zaninetti, L. \& Rowan, E. 2001. High genetic diversity and relative specificity among Symbiodiniumlike endosymbiotic dinoflagellates in soritid foraminiferans. Mar. Biol. 139:1069-78.

Pontasch, S., Scott, A., Hill, R., Bridge, T., Fisher, P. L. \& Davy, S. K. 2014. Symbiodinium diversity in the sea anemone Entacmaea quadricolor on the east Australian coast. Coral Reefs 33:537-42.

Ralph, P. J., Gademann, R. \& Larkum, A. W. D. 2001. Zooxanthellae expelled from bleached corals at $33^{\circ} \mathrm{C}$ are photosynthetically competent. Mar. Ecol. Prog. Ser. 220:163-8.

Reynolds, J. M. C., Bruns, B. U., Fitt, W. K. \& Schmidt, G. W. 2008. Enhanced photoprotection pathways in symbiotic dinoflagellates of shallow-water corals and other cnidarians. Proc. Natl. Acad. Sci. USA 105:13674-8. 
Roth, M. S., Goericke, R. \& Deheyn, D. D. 2012. Cold induces acute stress but heat is ultimately more deleterious for the reef-building coral Acropora yongei. Sci. Reports 2, 240:1-5. doi:10.1038/srep00240.

Sampayo, E. M., Ridgway, T., Bongaerts, P. \& Hoegh-Guldberg, O. 2008. Bleaching susceptibility and mortality of corals are determined by fine-scale differences in symbiont type. Proc. Natl. Acad. Sci. USA 105:10444-9.

Saxby, T., Dennison, W. C. \& Hoegh-Guldberg, O. 2003. Photosynthetic responses of the coral Montipora digitata to cold temperature stress. Mar. Ecol. Prog. Ser. 248:85-97.

Smith, D. J., Sugett, D. J. \& Baker, N. R. 2005. Is photoinhibition of zooxanthellae photosynthesis the primary cause of thermal bleaching in corals? Glob. Change Biol. 11:1-11.

Stat, M., Pochon, X., Cowie, R. O. M. \& Gates, R. D. 2009. Specificity in communities of Symbiodinium in corals from Johnston Atoll. Mar. Ecol. Prog. Ser. 386:83-96.

Steen, R. G. \& Muscatine, L. 1987. Low temperature evokes rapid exocytosis of symbiotic algae by a sea anemone. Biol. Bull. $172: 246-63$.

Stimson, J. \& Kinzie, R. A. 1991. The temporal pattern and rate of release of zooxanthellae from the reef coral Pocillopora damicornis (Linnaeus) under nitrogen-enrichment and control conditions. J. Exp. Mar. Biol. Ecol. 153:63-74.

Takahashi, S. \& Badger, M. R. 2011. Photoprotection in plants: a new light on photosystem II damage. Trends Plant Sci. 16:53-60.

Takahashi, S., Nakamura, T., Sakamizu, M., Van Woesik, R. \& Yamasaki, H. 2004. Repair machinery of symbiotic photosynthesis as the primary target of heat stress for reef-building corals. Plant Cell Physiol. 45:251-5.

Takahashi, S., Whitney, S. M. \& Badger, M. R. 2009. Different thermal sensitivity of the repair of photodamaged photosynthetic machinery in cultured Symbiodinium species. Proc. Natl. Acad. Sci. USA 106:3237-42.

Takahashi, S., Whitney, S., Itoh, S., Maruyama, T. \& Badger, M. 2008. Heat stress causes inhibition of the de novo synthesis of antenna proteins and photobleaching in cultured Symbiodinium. Proc. Natl. Acad. Sci. USA 105:4203-8.

Tchernov, D., Gorbunov, M. J., de Vargas, C., Yadav, S. N., Miligan, A. J., Haggblom, M. \& Falkowski, P. G. 2004. Membrane lipids of symbiotic algae are diagnostic of sensitivity to thermal bleaching in corals. Proc. Natl. Acad. Sci. USA 101:13531-5.

Thornhill, D. J., Kemp, D. W., Bruns, B. U., Fitt, W. K. \& Schmidt, G. W. 2008. Correspondence between cold tolerance and temperate biogeography in a western atlantic Symbiodinium (Dinophyta) lineage. J. Phycol. 44:1126-35.
Tyystjärvi, E. 2008. Photoinhibition of photosystem II and photodamage of the oxygen evolving manganese cluster. Coordin. Chem. Rev. 252:361-76.

Ulstrup, K. E., Hill, R., Van Oppen, M. J. H., Larkum, A. W. D. \& Ralph, P. J. 2008. Seasonal variation in the photo-physiology of homogeneous and heterogeneous Symbiodinium consortia in two scleractinian corals. Mar. Ecol. Prog. Ser. 361:139-50.

Urban, F. E., Cole, J. E. \& Overpeck, J. T. 2000. Influence of mean climate change on climate variability from a 155 -year tropical Pacific coral record. Nature 407:989-93.

Venn, A. A., Loram, J. E. \& Douglas, A. E. 2008. Photosynthetic symbioses in animals. J. Exp. Bot. 59:1069-80.

Venn, A. A., Wilson, M. A., Trapido-Rosenthal, H. G., Keely, B. J. \& Douglas, A. E. 2006. The impact of coral bleaching on the pigment profile of the symbiotic alga, Symbiodinium. Plant Cell Environ. 29:2133-42.

Veron, J. \& Done, T. 1979. Corals and coral communities of Lord Howe Island. Mar. Freshw. Res. 30:203-36.

Veron, J. E. N. \& Stafford-Smith, M. 2000. Corals of the World, 3 Volumes. Australian Institute of Marine Science, Townsville, QLD.

Warner, M. E. \& Berry-Lowe, S. 2006. Differential xanthophyll cycling and photochemical activity in symbiotic dinoflagellates in multiple locations of three species of Caribbean coral. J. Exp. Mar. Biol. Ecol. 339:86-95.

Warner, M. E., Fitt, W. K. \& Schmidt, G. W. 1999. Damage to photosystem II in symbiotic dinoflagellates: a determinant of coral bleaching. Proc. Natl. Acad. Sci. USA 96:8007-12.

Weis, V. M. 2008. Cellular mechanisms of Cnidarian bleaching: stress causes the collapse of symbiosis. J. Exp. Biol. 211:305966.

Wicks, L. C., Hill, R. \& Davy, S. K. 2010b. The influence of irradiance on tolerance to high and low temperature stress exhibited by Symbiodinium in the coral, Pocillopora damicornis, from the high-latitude reef of Lord Howe Island. Limnol. Oceanogr. 55:2476-86.

Wicks, L. C., Sampayo, E., Gardner, J. P. A. \& Davy, S. K. 2010a. Local endemicity and high diversity characterise high-latitude coral-Symbiodinium partnerships. Coral Reefs 29:9891003.

Zapata, M., Rodriguez, F. \& Garrido, J. L. 2000. Separation of chlorophylls and carotenoids from marine phytoplankton: a new HPLC method using a reversed phase C-8 column and pyridine-containing mobile phases. Mar. Ecol. Prog. Ser. 195:29-45. 